\title{
Human Immunodeficiency Virus Infection: from Biological Observations to Mechanistic Mathematical Modelling
}

\author{
G. Bocharov ${ }^{1}$, V. Chereshnev², I. Gainova ${ }^{3}$, S. Bazhan ${ }^{4}$, B. Bachmetyev ${ }^{5}$, \\ J. Argilaguet, ${ }^{6}$ J. Martinez, ${ }^{6}$ A. Meyerhans ${ }^{6 * *}$ \\ ${ }^{1}$ Institute of Numerical Mathematics, RAS, Moscow, Russia \\ 2 Institute of Immunology and Physiology, Ural Branch RAS, Ekaterinburg, Russia \\ ${ }^{3}$ Sobolev Institute of Mathematics, Siberian Branch RAS, Novosibirsk, Russia \\ ${ }^{4}$ State Research Center of Virology and Biotechnology "Vector", Novosibirsk Region, Koltsovo, Russia \\ ${ }^{5}$ Institute of Ecology and Genetics of Microorganisms, Ural Branch RAS, Perm, Russia \\ ${ }^{6}$ ICREA Infection Biology Laboratory, Department of Experimental and Health Sciences, \\ Universitat Pompeu Fabra, Barcelona, Spain
}

\begin{abstract}
HIV infection is multi-faceted and a multi-step process. The virus-induced pathogenic mechanisms are manifold and mediated through a range of positive and negative feedback regulations of immune and physiological processes engaged in virus-host interactions. The fundamental questions towards understanding the pathogenesis of HIV infection are now shifting to 'dynamic' categories: (i) why is the HIV-immune response equilibrium finally disrupted? (ii) can one modify the dynamic equilibrium for host benefit? (iii) can one predict the outcome of a system perturbation via antiviral drugs or drugs modulating the host immune response dynamics? Answering these questions requires a major interdisciplinary effort, and in particular, the development of novel mathematical approaches for a coherent quantitative description and prediction of intra-patient HIV evolution, the immunological responses to HIV infection, and the systems level homeostatic regulation of specific effector and regulatory lymphocyte populations in correlation with disease status. Here we summarized fundamental biological features of HIV infection and current mathematical modelling attempts to understand HIV pathogenesis.
\end{abstract}

Keywords and phrases: mathematical modelling, host-pathogen interaction, immune system, human immunodeficiency virus infection

Mathematics Subject Classification: 35Q92, 37N25, 92-02, 92B05, 92C30, 92C42, 93A30, 97M60

\footnotetext{
${ }^{*}$ Corresponding author. E-mail: bocharov@inm.ras.ru

** Corresponding author. E-mail: andreas.meyerhans@upf.edu
} 


\section{Introduction}

It has been almost 30 years since the discovery of the Human Immunodeficiency Virus (HIV) as the causative agent of AIDS $[20,78,138,153,196]$. Today, the HIV/AIDS pandemic affects about 35 million people worldwide, with an estimated 2.7 million new infections and 1.8 million AIDS-related deaths only in the year 2010 [263]. Even with the successful suppression of the virus by current Highly Active Antiretroviral Therapy (HAART) [9], the infection cannot be cured. Moreover, there is no effective vaccine available [146]. Reasons for these caveats are directly associated with two essential features of HIV. First, the HIV provirus can become latent in the target cell and therefore remain undetected by the immune response $[75,233]$ and current drug regimen. Second, the high intra-host diversity of HIV can drive the emergence of drug resistance [9] and reduce immune recognition [91,252].

With the advent of new research tools our understanding of the HIV-host interaction has grown enormously in the last years. High-throughput screening (HTS) campaigns using siRNA have led to the identification of host factors either supporting or restricting HIV replication, thus opening the door for new therapeutic options $[32,39,126,139,181,200,268,274]$. In particular, current research efforts are focused on depleting the latent HIV reservoir [54]. It has been proposed that crucial host transcription factors, such as NF-kB and NFAT, can be agonistically targeted to reactivate HIV from latency, thus allowing stimulated cytolytic T lymphocytes (CTL) to kill off infected cells [222]. Similarly, uncoiling HIV proviral DNA by targeting histone deacetylases (HDACs) and histone methyltransferases (HMTIs) has also been proven effective in reactivating the virus from latency [31,163]. Furthermore, there is increasing evidence that HIV requires components of the cellular kinase signalling pathways for its replication, providing further options for the development of new antiviral strategies in the near future [158, 200, 229].

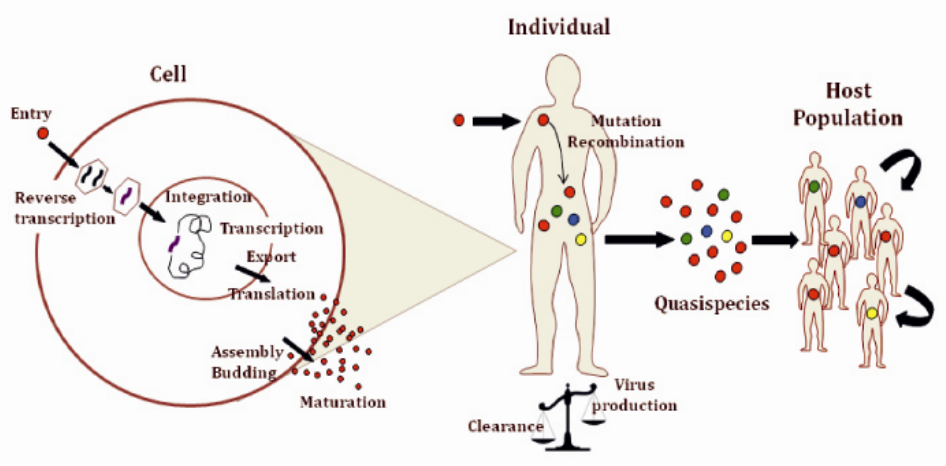

FIGURE 1. HIV biology at the level of an infected cell, an infected host organism and spreading within a host population. The consequences of the events of HIV replication at the cellular level are reflected in the infected individual that in turn determines the outcome at the host population level. 
Despite the impressive research advances of the last years, an integrative view and quantitative understanding of the mechanisms of HIV-induced pathogenesis has not been fully achieved. This is in part due to the "language barrier" and knowledge gaps between mathematical modellers, immunologists and clinical and basic virologists. To reduce these gaps, this review summarizes the basic features of HIV biology that may be considered for an implementation into explanatory models of virus-induced pathogenesis (see Figure 1). Models of HIV epidemiology (see i.e. [197]) represent a separate field of research and are not considered here. Interested readers may also look at two recent reviews on basic HIV biology from another perspective [71,136]. Subsequently, previous modelling attempts are described that analyse certain aspects of intra-patient HIV evolution, the immunological responses to HIV infection, and the homeostatic regulation of specific $\mathrm{T}$ lymphocyte populations in correlation with disease. Together this may contribute to joint research efforts addressing neglected areas of fundamental biological and disease-associated processes in HIV infection.

\subsection{HIV infection at the level of a cell}

The cellular journey of HIV is a complex struggle between cellular defence mechanisms and viral-encoded counterparts $[39,136,139]$. HIV primarily infects CD4+ T cells and macrophages. Entry into a target cell is mediated by the interaction between the viral envelope, the cellular CD4 receptor, and the chemokine receptors CCR5 and/or CXCR4, which altogether determines the tropism of HIV. Once inside the cytoplasm, the viral-encoded reverse transcriptase (RT) catalyses the conversion of both single-stranded RNA genomes into one DNA molecule using deoxynucleotide triphosphates (dNTPs) as building blocks. The host restriction factor SAMHD1 can interfere at this step by downregulating intracellular dNTP levels [214]. Likewise, other retroviral restriction factors act at this early infection stage to dampen down virus expansion. These are TRIM $5 \alpha$, that recognises retroviral cores and mediate their structural disintegration, and APOBEC 3 proteins that deaminate cytidines in single-stranded viral DNA regions with the consequence of DNA degradation or hypermutation [109,148,159,164,245,253,272]. To overcome host restriction, HIV has developed counterparts like Vif and Vpu that interact with the restriction factors and target them to proteasomal degradation [121,147, 179, 180, 225, 250].

Reverse transcription is the step within the viral life cycle in which point mutations and recombination events occur $[127,152,162,184,202]$. These are together with APOBEC-mediated hypermutation the main mechanisms in generating virus diversity. Subsequently, the HIV DNA is trafficked to the nucleus and integrated into the host chromosome with the help of the viral integrase. This HIV provirus may remain silent as a so-called latent provirus or use the cellular transcription and translation machinery to produce viral mRNAs and proteins that assemble to progeny virions at the cell surface. Infection of new target cells may then occur via cell-free virus or by cell-to-cell transfer through actin structures named virological synapses [212]. These late stages of the virus life cycle are utilizing the cellular transport machinery by means of the endosomal sorting complex (ESCRT) [22] and can be inhibited by the restriction factor BST-2/Tetherin $[179,180,250]$. Again as mentioned above, HIV has acquired a counterpart in form of the $\mathrm{Vpu}$ protein that interacts with the restriction factor and targets it to proteasomal degradation.

\subsection{HIV infection at the level of a host organism}

Already the events during primary HIV infection of a human set the stage for the following dynamic interaction between the virus and immune-physiological responses of the host that dictates the course of the infection (reviewed in [29,42,168,231]; see Figure 2 for main infection characteristics). In about $80 \%$ of cases, initiation of the infection is a clonal event $[116,134]$. The transmitted virus grows exponentially which in turn induces strong innate and adaptive immune responses including acute phase proteins [144], the cytokine cascade $[133,204,239]$, B cell $[151,248]$ and $\mathrm{T}$ cell responses [89,244]. This is associated with a significant depletion of the CD4 $\mathrm{T}$ cell pool. The depletion is most profound and irreversible in the gut-associated lymphoid tissue $[34,51,154,187,199]$. An explanation may be the observed ability of the envelope gp120 protein of transmitted founder virus to interact with the gut mucosal homing receptor $\alpha 4 \beta 7$ on mucosal CD4 T cells $[8,176]$. Associated with the destruction of the gastrointestinal 
lymphoid tissue, the translocation of bacterial products like lipopolysaccharides (LPS) provides a stimulus to systemic immune activation thus fueling new bursts of productive virus infections, $\mathrm{T}$ cell proliferation and death $[97,101]$.

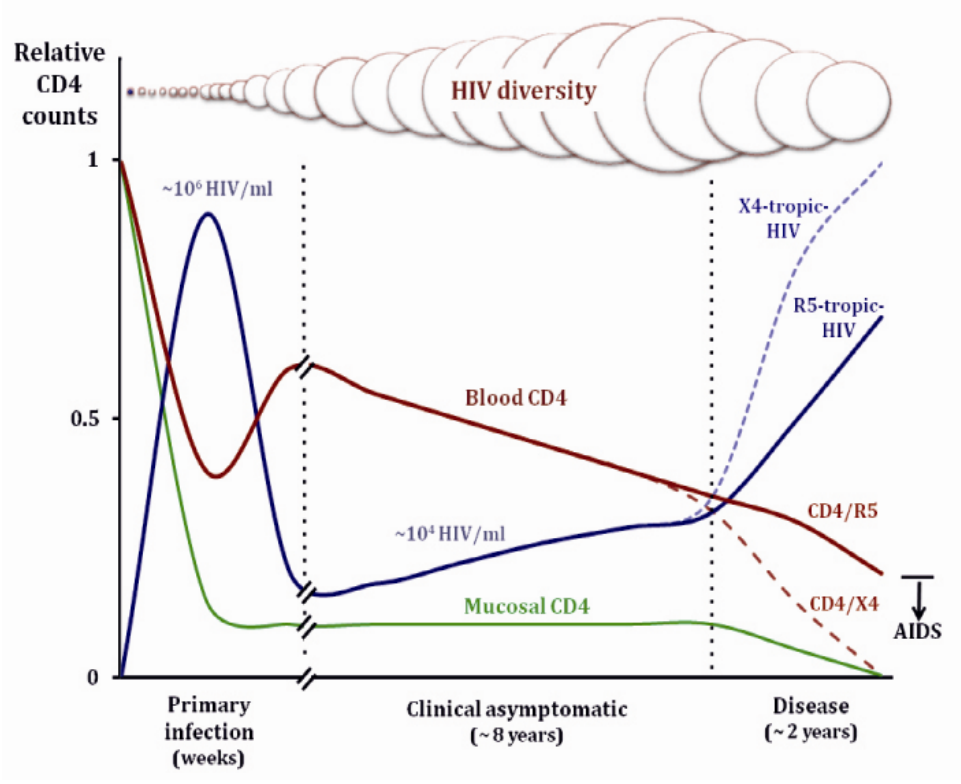

FIgURE 2. Typical course of an HIV infection. HIV infection has been classically divided into 3 stages based on viral load in plasma, decline of CD4+ T cells and clinical symptoms. The primary infection lasts a few weeks and is characterized by high peaks in viral load in the blood (viremia) and a fast decline in CD4+ T cell counts. After this acute phase of infection, the CD4 $+\mathrm{T}$ cell counts in blood partially recover and viremia decreases however the mucosal CD4+ T cell numbers remain low. During the long lasting clinical asymptomatic phase there is an apparent equilibrium between CD4 counts and viremia. Continuous virus replication then leads to the continuous destruction of the $\mathrm{CD} 4+\mathrm{T}$ cell pool and progression of immunodeficiency. The final disease phase $(=$ AIDS) is defined by CD4+ T cell counts lower than $200 / \mu \mathrm{l}$ blood and is characterized by the appearance of opportunistic infections that ultimately lead to death of the infected individual when not appropriately treated by antiretroviral therapy. In about $50 \%$ of HIV-infected individuals, a co-receptor switch (from CCR5 to CXCR4, solid and dashed lines, respectively) of the virus is observed that is associated with a faster decline in CD4+ T cell counts. During the infection course, HIV diversity and complexity is mostly increasing but reduces towards the end (circles, see text for details).

The peak of HIV viremia is limited primarily by virus-specific CD8-positive T lymphocytes [89,244]. Depending on the nature of the founder virus and the strength of the CTL response, the virus load decreases and stabilises at some level known as the viral set point [168]. This set-point is highly variable amongst infected individuals and is, together with chronic immune activation, a predictor of disease progression $[86,170,171,238]$. A low virus set point correlates with a reduced decline in peripheral blood CD4 T cells and a longer time of the chronic infection phase until the onset of AIDS. In parallel to disease progression, a functional exhaustion of HIV-specific CTL has been observed [19,62,262,267]. This immune dysfunction has the straightforward consequence of reducing virus control. Without antiretroviral 
treatment, the HIV load slowly increases until the final AIDS stage at which the number of CD4 T cells have dropped below a critical level that is required for a proper functioning of the immune system.

A fundamental feature of HIV is error-prone replication together with its ability to multiply infect single cells. As a consequence the clonal infecting founder virus rapidly accumulates genetic mutations by point mutations and recombinations, and generates a mutant spectrum collectively called "HIV quasispecies" $[88,172]$. The evolution of the viral quasispecies is determined by the mutation processes as well as by fitness-based selection and random sampling (see accompanying review of Domingo and Perales). Mutations in regions of HIV proteins that are recognized by HIV-specific CTL confer a selective advantage over un-mutated virus resulting from a decrease in elimination [168]. However this may be at the cost of a reduction in the efficacy of mutated virus replication. Experimental analysis of HIV quasispecies evolution over time revealed a linear increase of both, the viral divergence from the founder virus and the diversity within the quasispecies in the initial infection phase [223]. Subsequently the divergence stabilizes and the diversity declines questioning the genetic diversity of HIV to be the key factor for disease progression.

Despite considerable progress in the characterization of HIV host interactions (Table 1a and 2), several fundamental questions with respect to HIV pathogenesis remain unsolved. Why does the immune system fail to regenerate the depleted CD4 T cell compartment? Why is the apparent equilibrium of the HIV immune response finally disrupted? From the comparison of patient groups with varying disease progression rates and studies on progressive and non-progressive infection of immunodeficiency viruses of non-human primate animal models, several pathogenesis concepts have evolved: (i) chronic immune activation, (ii) depletion of mucosal CD4-positive memory T cells and (iii) CD4 central memory T cell population failure $[97,99,101]$. Resolving these and other pathogenesis issues as mentioned in Table 1b will require a major interdisciplinary effort, in particular the development of novel mathematical modelling approaches that are consistent with the complexity of the HIV host interaction and are able to integrate recent large-scale data sets derived from systems biology studies in humans and animal models [30,73,125,149,157,206].

\subsection{HIV at the host population level}

Major initial steps towards prevention of HIV spread in humans were the recognition of how the virus is transmitted and the establishment of diagnostic serological tests (Table 1a). The era of antiretroviral therapy (ART) then started in the late $80^{\prime} \mathrm{s}$ with the introduction of the first drugs specifically targeting viral enzymes [9]. ART has proven effective in reducing HIV spread including vertical transmission, and has been proposed for pre-exposure prophylaxis $[1,92,102]$. After the observation that circumcised men exhibit a lower risk of becoming infected [166], circumcision is now considered as an important prevention tool.

The development of a successful vaccine, both for the prevention of a HIV infection or as an immunotherapeutic tool in the context of an already existing infection, has remained elusive. Early vaccine trials failed to generate neutralizing antibodies against strains other than the ones used to produce the vaccines and showed no evidence for protection $[128,167]$. The subsequent STEP trial has even provided evidence for enhanced HIV susceptibility [38]. However, the recent RV144 trial in Thailand reported a mild $30 \%$ of protection [201] raising hopes that protection is achievable. In this context, ongoing studies with elite controllers and long-term nonprogressors might provide further clues of how to produce new and more effective vaccines $[23,72]$.

\section{Mathematical models of HIV infection}

In addition to hypothesis-driven human clinical trials, some insights into the pathophysiology of HIV infection are gained using modelling approaches including the in vitro culture systems, the in vivo animal models (humanized mouse-, transgenic rodent-, non-human primate models) and mathematical models [242]. To handle the analysis of immunological, virological and physiological processes underlying the variation between individuals in the dynamics of acute and chronic phases of HIV infection in 
an integrated manner, a major interdisciplinary effort is required, and in particular, the development of novel mathematical approaches for a coherent description and quantitative, dynamic analysis of an intra-patient HIV evolution and the immuno-physiological responses. Obtaining a quantitatively correct and predictive mathematical model of HIV infection that will provide accurate estimates of the scale of events is a challenge that has not been routinely implemented in many efforts at modelling of HIV infection. The mathematical models developed so far to address various aspects of HIV infection (see Table 3) can be subdivided into descriptive-, explanatory- and predictive ones. In general, the model equations are formulated by putting together elementary functional forms (building blocks) for the growth, death, differentiation, etc. processes rather than by deriving constitutive equations from the first principles of physics (e.g. conservation of mass and energy). Typically, researchers borrow concepts from ecology, enzyme kinetics or epidemiology, making use of the mass action law to formulate equations and describe the dynamics by systems of ordinary differential equations (ODEs). We review representative modelling frameworks, which have been proven to be instrumental in enabling greater insight into quantitative parameters of virus-host interaction and the kinetic determinants of disease progression.

\subsection{Elementary models}

The broadly used (so called 'generalized consensus') basic model of HIV infection (see for further details [189]) describes the population dynamics of target cells (CD4 T cells, macrophages, dendritic cells) $T(t)$, productively infected cells $-I(t)$, and free virus $-V(t)$. The equations of the above T-I-V type model which consider the target cell production in thymus, their homeostatic proliferation at the periphery, virus infection, death and virus production, read as follows:

$$
\begin{aligned}
\frac{d}{d t} T(t) & =s+p T(t)\left(1-\frac{T(t)}{T_{\max }}\right)-d_{T} T(t)-k V(t) T(t), \\
\frac{d}{d t} I(t) & =k V(t) T(t)-\delta I(t) \\
\frac{d}{d t} V(t) & =N \delta I(t)-c V(t) .
\end{aligned}
$$

The set of equations can be further expanded to consider various types of heterogeneity in the HIVimmune system, e.g. types of infection (productive, latent), nature of target cells, virus escape mutations (see Table 4) $[80,182,189,254]$.

The above type of models for virus dynamics is seriously deficient as the immune response to HIV is not considered. The extended versions describe the population dynamics of immune, mostly the cytotoxic T lymphocyte response in a simple way using various functional forms which relate the proliferation term to the abundance of virus or target cells in the host [182]. The general form of the CTL dynamics $E(t)$, which considers cell production in the thymus, their normal death, HIV-induced proliferation and impairment of immune responses observed in HIV infection, can be specified as follows (see for the details $[2])$ :

$$
\frac{d}{d t} E(t)=\lambda_{E}-d_{E} E(t)+\left\{f_{d i v}\left(V, I, T, p_{d i v}\right) E(t)-f_{i m p}\left(V, I, T, p_{i m p}\right) E(t)\right\} .
$$

The model can be further expanded to take into account different CTL states (naïve, memory, anergic, effector, etc.) and types of regulations underlying the transitions between the states [208]. The combination of virus and immune response dynamics (modules (2.1) and (2.2)) with proper modification of the infected target cell equation to account for the CTL-mediated elimination provides a tool to qualitatively explore the impact of various parameters of virus-host interaction and antiviral treatment regimes on HIV infection dynamics [2]. Note that the parameterization of the dependence of immune responses on HIV infection characteristics deserves further attention as their long-term regulation in the chronic phase is poorly understood. 
G. Bocharov, V. Chereshnev, I. Gainova, S. Bazhan, B. Bachmetyev, J. Argilaguet, J. Martinez, A. Meyerhans Human Immunodeficiency Virus Infection

\subsection{Short-term descriptions of HIV infection}

High viral load and severe loss of CD4 T cells in mucosal compartments are a hallmark of acute HIV infection (see Figure 2). The course of acute infection is determined by the development of innate and then adaptive immune responses. Activation of the host immune system is considered to be a key factor of the pathogenesis of HIV infection (see Table 1b).

\subsubsection{Innate immune responses}

Dendritic cells (DC) and natural killer cells (NK) are the principal mediators of innate immune responses. DCs can both induce the antiviral adaptive response and promote the spread of the virus. There are few mathematical models that were developed to examine the above duality issue. An ODE based model developed in [119] considered the population dynamics of cell-virus interactions for CD4 T cell, CD8 $\mathrm{T}$ cells, DCs and HIV. The immune cells were further subdivided into subsets representing different activation/maturation states. The parameters were assessed from published sources. Sensitivity analysis was used to evaluate the effect of particular interactions and depletion of specific cell populations. A more detailed quantitative model of the initial inflammatory response to HIV invasion has recently been published [261]. It considers the population dynamics of 17 subsets of immune cells, including DCs, helper CD4 $\mathrm{T}$ cells and regulatory CD4 $\mathrm{T}$ cells. The model is formulated with ODEs and takes into account the birth/death-, contact/interaction and migration processes. The parameters of the model were quantified using elaborate procedures based upon sensitivity analysis and ordinary least squares fitting. This calibrated and validated inflammatory response model can be further used as an "elementary" building module for setting up multi-scale mathematical descriptions of HIV.

\subsubsection{Adaptive immune response}

A first quantitative modelling of the adaptive immune response in the primary HIV infection using patient's data was implemented in [240]. The authors used a phenomenological description of the impact of CTL response parameterized via viral load on the elimination rate of the infected cells. The parameters of the model were estimated using the log-least squares distance criterion and clinical data covering the time range of up to 500 days post infection. The mathematical description of the CTL response was further refined in [49]. To this end the authors extended the model by equation for the rate of change of the CTL population in which the birth term was assumed to be linearly dependent on the abundance of target cells. A time delay between the infection and appearance of the differentiated effector cells was taken into account. The ODE and DDE versions of the model were compared by analyzing the consistency with the clinical data of the corresponding best-fit solutions. Different functional forms to model the regulation of CTL responses were examined in [49]. In particular, the authors assumed a bounded rate function of the number of infected cells in the proliferation terms. The calibrated model was shown to reproduce diverse patterns of virus kinetics observed in primary HIV infection.

In addition to deterministic models, there exist few stochastic models of early HIV infection (Table 4). The model formulated with stochastic differential equations proposed in [132] is an extension of an ODE model of T-I-V type obtained by considering additive noise terms in the form of Wiener processes. A different stochastic approach utilizing the branching-process framework to model the interaction between the virus, target cells of monocyte type and T cells can be found in [264]. The stochastic models are particularly suitable to analyze extinction events in the context of immune or antiviral interventions.

\subsubsection{Chronic infection}

Following the acute infection phase, virus level declines to a set point thus establishing a chronic phase of infection which can be interpreted as a quasi-steady state of the virus-host system (see Figure 2). The mathematical models for the chronic phase HIV infection developed so far are based upon the use of the same simple modules like the basic model of virus dynamics $[182,189]$. Some important estimates of HIV infection parameters provided by fitting the models of the above family to clinical data were obtained in [175] (Table 2). The impact of escape from immune responses on viral load was estimated in [131]. A single escape event was shown to result in a viral load increase during the chronic phase by $10 \%$ to $50 \%$. 
However, only $6 \%$ of between-individual variation in viral load could be explained by the escape events. Using data from Los Alamos National Laboratory sequence repository and longitudinal studies, a simple exponential growth model for HIV was utilized to estimate the selective advantage of escape mutants, i.e. the relative rate of escape (see Table 2) [11].

Longitudinal clinical data sets, which are available for the chronic phase of HIV infection, are important for the validation of mathematical models. Instructive examples are presented in $[3,17]$. The predictive capability of the long-term models was assessed by comparing the model simulations with parameters estimated from half of the longitudinal data sets to full data sets. The so calibrated models were further used to explore treatment strategies via optimal control methods $[4,18,61,205]$.

\subsection{Long-term descriptions of HIV infection}

To describe the long-term course of HIV infection from the initial acute infection phase through chronic persistence to AIDS, the basic model of virus replication is used being supplemented by the equations that simulate the immune response and, importantly, reflect specific hypothesis regarding the impairment of the homeostatic regulation of $\mathrm{T}$ cell populations in lymphoid tissues and blood. The corresponding parameterizations of the functional forms can be rather elaborate however they have in common that they use time-dependent or resource-dependent factors that introduce instability of the quasi steady state.

One of the first models to describe the whole HIV infection course in terms of $\mathrm{T}$ cell counts rather than viral load was proposed in [120]. The model structure reflects the assumptions about two feedback loops, one coming from the CTL mediated destruction of HIV infected CD4 T cells (negative feedback) and the other takes into account the dependence of CTL proliferation on CD4 T cell abundance (positive feedback). The model structure was sufficiently rich to describe the data on kinetics of CD4 and CD8 T lymphocytes over a seven year period.

Realistic modelling of HIV infection requires consideration of virus population dynamics which is regarded as a 'moving target' [237] for the immune system because of the emergence of virus mutants. The model proposed in $[106,107]$ was used to predict the entire trajectory of the HIV infection spanning about ten years. The population dynamics of macrophages, CD4 T cells, wild type- and mutant virus, and CTLs was described using a combination of the T-I-V type (2.1) and E-type (2.2) basic models. In the corresponding equations the bounded rate forms for proliferation terms and bilinear interaction terms were considered. Remarkably, the model was calibrated by the clinical data for typical progressors and long-term non-progressors. The model was further extended by considering the pharmacokinetic module in order to explore the options for patient-specific treatment with three antiretroviral drugs (RDV, 3TC, ZDV). Overall, the study provided the list of kinetic model parameters for a comparative analysis of rapid- versus typical progressors and long-term non-progressors [107]. The specified values confirm the point stated in [175] that variations in multiple parameters can (and are enough to) account for large variations in HIV dynamics. A bifurcation analysis of the simplified version of the model proposed in [106] was further applied in [117] to reveal a subset of parameters which may produce two distinct types of steady states: a stable one, corresponding to individuals who do not develop AIDS and the second, unstable one, representing patients who develop AIDS in about 10 years.

A simple quantitative mathematical model to describe the long-term kinetics of HIV infection with a focus on the effect of immune activation, the key element of HIV pathogenesis, on CD4 and CD8 T cell populations and on the maintenance of infection through the activation of infected resting memory $\mathrm{T}$ cells was proposed in [40]. The immune activation was assumed to induce programmed cell death in $\mathrm{T}$ lymphocytes, which was parameterized via bi-linear functions of the number of activated infected $\mathrm{T}$ cells. The parameters of the model were estimated via least squares function minimization using some published clinical data on $\mathrm{T}$ cells and viral load dynamics. The biological consistency of the model was further examined via bifurcation and the sensitivity analysis of the solution. The analyses revealed the increasing correlation between apoptosis and infection-immune response parameters with the time of infection. 
A detailed mathematical model for the host's immune response to HIV infection was proposed in [259] to examine the sensitivity of the global infection dynamics to the model parameters. The model was calibrated to reproduce essential features of CD4 T cells and viral load dynamics, including the establishment of viral load set point, steady state and development of AIDS. The state space of the model (15 time-dependent variables) spanned CD4- and CD8 T lymphocytes subdivided into uninfected-infected, virus-specific and non-specific subsets, infected and uninfected macrophages, HIV-specific neutralizing antibodies and viral load. The decline of the thymic function with aging and the mutation-induced changes in the virus cell tropism were taken into account in the model. The functional forms for the processes considered in the model were specified using bilinear- and bounded rate functions. The study provides a rich analytical source of the estimates of virus-host interaction parameters (more than 35). It was shown that $10 \%$ variation of the model parameters is enough to mimic individual host differences in the dynamical patterns of HIV infection.

A hybrid computational model of HIV-1 infection has been proposed recently to study optimal therapy regimes [185]. The model is based on agent-based description of the interaction between the following populations: viruses, antibodies, macrophages, dendritic cells, CD4 T cells, CTLs, B lymphocytes and plasma cells. The virus population is represented as a set of two binary strings of length 16, corresponding to B-cell and T-cell epitopes, respectively. The Hamming distance is used to determine the affinity of the interaction. To take the spatial aspects of the interaction between the above entities into account, lymph nodes are represented as three-dimensional ellipsoid lattices with periodic boundary conditions. The spatio-temporal evolution of the concentration of small molecular weight molecules (interleukins and chemokines), $c(t, x)$, is described using the following type of reaction-diffusion equation with diffusion-, decay- and source terms on the right-hand side:

$$
\frac{\partial}{\partial t} c(t, x)=D \nabla^{2} c(t, x)-\lambda c(t, x)+s(t, x)
$$

Finally, the model also includes the intracellular level of description by considering antigen digestion and presentation within a single cell. The parameters of the model were calibrated to describe a broad range of acute HIV infection dynamics, viral set points, the variation in the elapsed times between infection and the onset of AIDS as observed in rapid-, normal-progressors and long-term non-progressors, and the mutation-selection mediated evolution of virus tropism [185]. Overall, this is a first multi-scale computational model (implemented as C-ImmSim simulator) which enables the analysis of the longterm spatio-temporal aspects of HIV infection dynamics via a combination of discrete stochastic- and continuum deterministic descriptions integrating the single cell- and cell population levels of resolution.

The activation of CD4 T cells by HIV and pathogens unrelated to HIV is considered as an important component of HIV pathogenesis. A mathematical model to study the effect of multiple $\mathrm{T}$ cell responses to many different antigens over time on the long-term dynamics of HIV infection was proposed in [76]. The dynamics of exposure to and clearance of antigens are described by stochastic differential equations for the probabilities of $\mathrm{T}$ cell activation coupled to deterministic equations for CD4 T cells, CD8 T cells and viral load dynamics with the activation and infected cell heterogeneity taken into account.

\subsection{Spatial representation of the immune system}

Spatial heterogeneity is an essential feature of HIV-1 infection. Unfortunately, this type of heterogeneity is practically unexplored via mathematical modelling approaches. Lymphoid organs are the major compartments supporting virus replication. Using a compartmental model of virus exchange between the populations of free virus and the virus bound to follicular dendritic cells in lymphoid tissues, free virus in plasma and other tissues cells, it was shown that lymphoid tissues represent the major sink compartment of the body with the virion clearance rate of 50 to 500 per day [63]. A first explicit consideration of the lymph node (LN) network was proposed in an agent-based model of HIV infection [192]. The model considers as agents the viruses, CD4 T cells, CD8 T cells and antigen-presenting cells. The LN network, implemented as 2-dimensional matrices, allows one to account for accurate localization of cells relevant 
for the cellular interactions as well as the circulation of immune cells between the nodes. The model was used to study the effect of the composition (e.g., the incorporation of gastrointestinal tract) of the network on the long-term progression of HIV infection.

\subsection{Models of HIV quasispecies}

HIV has enormous evolutionary potential so that the level of the genetic diversity of the HIV population changes in response to selection pressures. The specific issues that have been explored so far include the emergence of drug resistance and immune escape mutants, the effect of multiple target cell infections and recombination and the effective population size of the HIV replication-mutation processes. Mathematical models of the genetic evolution of HIV in the course of infection represent several approaches (Table 4).

One approach of HIV evolution modelling is based on the deterministic representation of the quasispecies theory [182]. It describes the population dynamics of growth-death of a set of virus mutants (vector $\mathbf{v}(t)$ ), which differ in their replication rate (fitness) and mutation probabilities, with systems of ODEs of the following structure:

$$
\frac{d}{d t} \mathbf{v}(t)=\mathbf{W} \mathbf{v}(t)-d(\mathbf{v}(t)) \mathbf{v}(t)
$$

Here, the matrix $\mathbf{W}$ depends on replication and mutation parameters, and $d(\cdot)$ parameterizes the decline due to finite life span and competition between the mutants. The deterministic quasispecies approach to analyze HIV evolution assumes that (is justified when) the population size $(N)$ is large enough, e.g. $N \gg 4^{L}$, where $L$ is the nucleotide length of the viral genome, $\sim 10^{4}$. The above inequality ensures that the frequency of a given mutation at any given time is predictable. In HIV infection, although the total viral population size (census) is large $\left(\sim 10^{12}\right)$, the effective population size of HIV is much smaller. It is estimated using mathematical methods to be in the range of $10^{3}-10^{5}$, depending on the underlying assumptions $[36,142,207]$. The small effective size of the virus population increases the role of random sampling so that the evolution shifts from fitness based selection towards the stochastic mode of random sampling (drift). A thorough analysis of the transition between stochastic evolution and deterministic evolution modes is presented in [209]. The authors use (a) the forward Kolmogorov equation which describes the evolution of the probability density function $\rho(t, f)$ of the mutant frequency $(f)$ under the effect of random drift $(N$ - population size), selection $(s-$ selection coefficient $)$ and mutation $(\mu-$ mutation rate) processes:

$$
\frac{\partial}{\partial t} \rho(t, f)=\frac{f_{\max }\left(1-f_{\max }\right)}{2 N} \frac{\partial^{2}}{\partial f^{2}} \rho(t, f)+s f_{\max }\left(1-f_{\max }\right) \frac{\partial}{\partial f} \rho(t, f)+\mu\left(2 f_{\max }-1\right) \frac{\partial}{\partial f} \rho(t, f)
$$

and (b) the discrete evolution equation describing the probability $p(t, n)$ of $n$ mutants at time $t$ as a Markovian process $p(t+1, n)=\sum_{n=0}^{N} P(n \mid n) p(t, n)$, see [209] for details.

The models were used to predict the stochastic versus deterministic modes of viral evolution in relation to the replication-mutation parameters such as the mutation rate, selection coefficient, and the effective population size.

In addition to mutation and selection, multi-infection of susceptible cells and subsequent recombination contribute to the genetic diversification of HIV population in the course of infection. However, incorporation of multi-infection and recombination into deterministic continuous descriptions (based on ODEs) is technically extremely elaborate as one can see from [15]. Simplified scenarios were studied in $[7,66]$ using integro-differential equation versions of the basic virus dynamics model.

The deterministic model proposed in [150] extends the standard T-I-V type of virus replication description by the variables denoting the number of doubly infected cells. The extended model was used to study the effect of recombination on the emergence of drug resistant genomes with specified number (1 to 5 ) of mutations, called the genetic barrier of the drug. The number of distinct mutant genomes 
considered in the model can be as large as 31, depending on the number of required mutations. However, the model ignores the existence of cells infected with more than two proviruses integrated into the cellular genome.

Genetic algorithms (GA) present a natural stochastic modelling tool to study the combined effect of mutation, recombination, selection and multi-infection [26,255]. To this end, the standard scheme of GA needs to be extended to take account of the multiplicity of target cell infection, which can range from 1 to 8 proviruses. The GA models implemented in $[26,255]$ were used to simulate the genomic diversification of HIV within an infected individual and to study the effects of variation in the fitness between the mutants, recombination and proviral copy number on the emergence of multi-point mutations. The simulations considered the virtual genomes coded as $2 \times 100$ bit strings and a population size of about 1000 . The study supported the view that in finite size virus populations the evolution of the mutant spectrum can be purely neutral and that multi-infection/recombination can accelerate the emergence of multi-point mutants.

\section{Conclusions}

In the analysis of the pathogenesis of HIV infection the focus of research is on understanding the robustness and fragility of "... a persistent state of immune activation, characterized by multiple, recurrent bursts of lymphocyte proliferation, differentiation, migration, death and functional modification of 'resting' cells, is associated with progressive depletion of central memory CD4+ T cells, and ultimately, a collapse of effector site CD4+ memory populations that is closely associated with overt immune deficiency" [97]. The ability to resolve these issues in human studies is obviously limited. Mathematical modelling has proven to be an important research tool in immunology [95]. The overview of the existing approaches to the complexities of virus-host interaction in HIV infection clearly indicates the gaps that require attention of applied mathematicians (Table 3). Models of HIV infection have traditionally assumed spatially homogeneous virus populations, ignoring the metapopulation structure of the infection process [77] and neglected the kinetic heterogeneity in virus production due to localized bursts of HIV infection sustaining the continuity of the infection process [96,97]. HIV replication (ontogeny) in infected cells requires a much more detailed analysis to identify the most sensitive stages for control. Importantly, the architecture (geometry and stromal organization) of immune responses in lymphoid tissues, which is disintegrated in the course of HIV infection, needs to be considered in the mathematical models. Finally, the data on global gene expression and regulation at a single cell level in HIV infection provide a fundamental source of information for ever finer understanding of the pathogenesis of HIV infection via a systems biology approach. Such a multi-scale integration using novel computational modeling and identification techniques should enable one, given the complexity of HIV infection, to utilize the inherent precision of the mathematical language to clearly differentiate among alternative hypothesis of HIV pathogenesis [95]. 
G. Bocharov, V. Chereshnev, I. Gainova, S. Bazhan, B. Bachmetyev, J. Argilaguet, J. Martinez, A. Meyerhans Human Immunodeficiency Virus Infection

Appendix

Table 1a. Important discoveries in HIV biology

\begin{tabular}{|c|c|c|}
\hline Level & Event & Ref. \\
\hline \multirow[t]{10}{*}{ Cell } & CD4 is the receptor for HIV & {$[60,138]$} \\
\hline & CCR5 and CXCR4 are the main HIV co-receptors & {$[52,59,69,270]$} \\
\hline & $\begin{array}{l}\text { HIV env interacts with } \alpha 4 \beta 7 \text { integrin of gut-homing } \\
\text { lymphocytes }\end{array}$ & {$[8,48,256]$} \\
\hline & HIV replicates in T cells and monocyte/macrophages & $\begin{array}{l}{[44,58,85,123,143,218,} \\
220,228]\end{array}$ \\
\hline & Dendritic cells capture HIV and transmit it to T cells & $\begin{array}{l}{[41,82,83,94,114,124,249,} \\
251,265]\end{array}$ \\
\hline & HIV life cycle is sensitive to intracellular dNTP levels & {$[156,173]$} \\
\hline & $\begin{array}{l}\text { Point mutations, recombination and hypermutation } \\
\text { contribute to HIV diversity }\end{array}$ & $\begin{array}{l}{[53,109,148,159,164,203} \\
253,272]\end{array}$ \\
\hline & Cell-cell transmission is efficient in HIV spread & $\begin{array}{l}{[165,193,198,210,212,227,} \\
232]\end{array}$ \\
\hline & HIV life cycle depends on multiple host factors & $\begin{array}{l}{[32,39,126,139,181,200,} \\
268,274]\end{array}$ \\
\hline & Multiple host factors can restrict HIV & $\begin{array}{l}{[121,147,179,180,224,225,} \\
245,250]\end{array}$ \\
\hline \multirow[t]{10}{*}{ Individual } & $\begin{array}{l}\text { First description of an acquired immunodeficiency in young } \\
\text { gay men }\end{array}$ & {$[90]$} \\
\hline & First isolation of HIV-1 and genome sequencing & {$[20,258]$} \\
\hline & First isolation of HIV-2 and genome sequencing & {$[50,103]$} \\
\hline & $\begin{array}{l}\text { HIV infection is a clonal event with } \alpha 4 \beta 7+\mathrm{CD} 4+\mathrm{T} \text { cells } \\
\text { as key targets }\end{array}$ & {$[116,134,176]$} \\
\hline & $\begin{array}{l}\text { HIV-infected individuals carry a heterogeneous virus } \\
\text { population referred to as a quasispecies }\end{array}$ & {$[5,88,108,172,266]$} \\
\hline & HIV multi-infection of single cells & {$[35,129,130,219,235]$} \\
\hline & Dynamic nature of HIV infection in vivo & {$[118,188,190,257,260]$} \\
\hline & $\begin{array}{l}\text { Viral set-point after primary infection and immune } \\
\text { activation are predictors for disease progression }\end{array}$ & {$[86,170,171,238]$} \\
\hline & Innate and adaptive immune responses after HIV infection & $\begin{array}{l}{[6,84,89,135,168,174,215,} \\
236,239,247]\end{array}$ \\
\hline & $\begin{array}{l}\text { HLA region polymorphisms in the host are major } \\
\text { determinants for disease progression and control }\end{array}$ & {$[191]$} \\
\hline
\end{tabular}


G. Bocharov, V. Chereshnev, I. Gainova, S. Bazhan, B. Bachmetyev, J. Argilaguet, J. Martinez, A. Meyerhans Human Immunodeficiency Virus Infection

Table 1a. Important discoveries in HIV biology (continued)

\begin{tabular}{|cll|}
\hline Level & \multicolumn{1}{c}{ Event } & \multicolumn{1}{c|}{ Ref. } \\
\hline \multirow{2}{*}{ Individual } & HIV replication in and destruction of lymphoid organs & {$[70,187,199]$} \\
& Early depletion of mucosal CD4 T cells & {$[34,51,154,169,217]$} \\
& HIV latency in memory T cells & {$[47,75,188,233]$} \\
& Exhausted T cell signature in chronic HIV infection & {$[19,62,262,267]$} \\
& HAART blocks disease progression & {$[13,137,213,241$,} \\
& & $246]$ \\
Host population & Diagnostic test to detect HIV infection & {$[37,211]$} \\
& HIV is transmitted by blood products, sexual contact and & {$[25,27,64,87,105$,} \\
& breast feeding & $141,155,177,221]$ \\
& ART reduces mother-child transmission & {$[102]$} \\
& HAART reduces HIV spread & {$[55,67]$} \\
& Pre-exposure prophylaxis reduces HIV spread & {$[1,92]$} \\
& Circumcision reduces HIV transmission & {$[14,16,28,166]$} \\
Vaccine-mediated enhancement of HIV spread (STEP trial) & {$[38]$} \\
First vaccine trial with evidence of low efficacy (RV144 & {$[110,201]$} \\
trial) & \\
\hline
\end{tabular}

Table 1b. Major conceptual developments in the understanding of HIV pathogenesis at the level of the individual

\section{Event}

Ref.

Clinical latency during the chronic phase of the disease does not correspond to latency of the virus

Immune activation is a major driving force of disease progression

$[10,24,45,65,86,98,112$ $216,226,234,257]$

Elevated lymphocyte turn-over in chronic infection is not a homeostatic

$[56,96,99,100,111,113]$ response to cell loss

Loss and/or dysfunction of central memory and naive cells rather than that of effector and effector-memory cells is a leading process in disease progression

The majority of latently-infected cells does not constitute a quiescent archive of virus but is a highly dynamic pool that is likely to be involved in driving the pathogenic process

Bacterial translocation is a major driver of chronic immune activation

$[186,187,257]$

Lymphoid tissue destruction is associated with chronic activation and disease progression

$[97,98,183,195,234]$

$[96,140,238,243]$

$[33,68]$

$[104,199,271]$ 
G. Bocharov, V. Chereshnev, I. Gainova, S. Bazhan, B. Bachmetyev, J. Argilaguet, J. Martinez, A. Meyerhans Human Immunodeficiency Virus Infection

Table 2. Fundamental parameters of HIV infection

\begin{tabular}{|c|c|c|c|}
\hline Parameter & Unit & Estimate [range] & Ref. \\
\hline Total viral load & $\begin{array}{l}\text { Virions in the lym- } \\
\text { phoid tissue (LT) }\end{array}$ & $10^{10}\left[7 \times 10^{9}, 10^{11}\right]$ & {$[175]$} \\
\hline $\begin{array}{l}\text { Total number of CD4 (CD8) T cells } \\
\text { in humans }\end{array}$ & Cells & $2 \times 10^{11}\left(10^{11}\right)$ & {$[79]$} \\
\hline $\begin{array}{l}\text { Abundance of lymphocytes in blood } \\
\text { vs. LNs and spleen }\end{array}$ & Relative fraction & $2.2 \%$ vs. $56.4 \%$ & {$[79]$} \\
\hline $\begin{array}{l}\text { CD4 T cell (CD8) level in normal vs. } \\
\text { HIV-infected individuals }\end{array}$ & Cell / $\mu l$ & $\begin{array}{l}1300 \pm 452 \text { vs. } 432 \pm 241 \\
(618 \pm 257 \text { vs. } 966 \pm 484)\end{array}$ & {$[115]$} \\
\hline $\begin{array}{l}\text { Production rate of CD } 4 \text { T cells (CD8) } \\
\text { for blood in normal vs. } \\
\text { HIV-1 infected individuals }\end{array}$ & Cell / $\mu l$ / day & $\begin{array}{l}10.4 \pm 6.5 \text { vs. } \quad 9.0 \pm 4.8 \\
(5.9 \pm 7.6 \text { vs. } 24.6 \pm 13.4)\end{array}$ & {$[115]$} \\
\hline $\begin{array}{l}\text { Death rate of CD } 4 \text { T cells (CD8) } \\
\text { in normal vs. HIV-1 infected } \\
\text { individuals }\end{array}$ & $1 /$ day & $\begin{array}{l}0.008 \pm 0.005 \text { vs. } 0.029 \pm \\
0.013(0.009 \pm 0.013 \text { vs. } \\
0.029 \pm 0.013)\end{array}$ & {$[115]$} \\
\hline Number of productively infected cells & $\begin{array}{l}\text { Cells per LT }(700 \mathrm{~g}) \\
\text { of the host }(70 \mathrm{~kg})\end{array}$ & $10^{8}\left[10^{8}, 7 \times 10^{8}\right]$ & {$[175]$} \\
\hline $\begin{array}{l}\text { Death rate of productively infected } \\
\text { cells }\end{array}$ & $1 /$ day & $0.5-4$ & {$[175]$} \\
\hline Clearance rate of free virus & $1 /$ day & $12[2.2,18]$ & {$[74]$} \\
\hline Infection rate of target cells & 1 / virion / day & $\begin{array}{l}8.5 \times 10^{-11} \\
{\left[5 \times 10^{-12}, 10^{-10}\right]}\end{array}$ & {$[175]$} \\
\hline Rate of production of target cells & Cell / day & $2 \times 10^{9}\left[10^{9}, 7 \times 10^{9}\right]$ & {$[175]$} \\
\hline $\begin{array}{l}\text { Selective advantage of escape (mu- } \\
\text { tant) variant* }\end{array}$ & $1 /$ day & $0.001-0.5$ & {$[11]$} \\
\hline Effective recombination rate & $\begin{array}{l}\text { Recombination / } \\
\text { base / generation }\end{array}$ & $\sim 10^{-5}$ & {$[21,178]$} \\
\hline 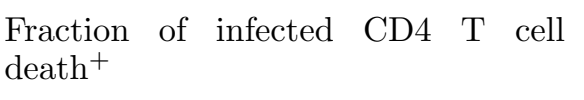 & & $2 \%$ & {$[12]$} \\
\hline Transmission probability & & $10^{-2}-10^{-3}$ & {$[93]$} \\
\hline $\begin{array}{l}\text { Number of founder virus per host } \\
\text { infection }^{\text {a }}\end{array}$ & & 1 & {$[134]$} \\
\hline Provirus copy number & & $1-8$ & {$[130,219]$} \\
\hline
\end{tabular}

* Increase in the exponential growth rate;

+ Attributable to CTLs recognizing a single epitope;

a In $80 \%$ of infections 
G. Bocharov, V. Chereshnev, I. Gainova, S. Bazhan, B. Bachmetyev, J. Argilaguet, J. Martinez, A. Meyerhans Human Immunodeficiency Virus Infection

Table 2. Fundamental parameters of HIV infection (continued)

\begin{tabular}{|c|c|c|}
\hline Parameter & Estimate [range] & Ref. \\
\hline $\begin{array}{l}\text { Half life of HIV-infected cells } \\
\text { in vitro } \mathbf{b}\end{array}$ & 4-8 days & {$[46,145]$} \\
\hline Virus production / day & $10^{10}$ & {$[190]$} \\
\hline Half life of latent reservoir ${ }^{\mathbf{c}}$ & 6-44 months & {$[75,233]$} \\
\hline $\begin{array}{l}\text { Virus load in plasma of untreated } \\
\text { individuals }\end{array}$ & $10^{2}-10^{7} \mathrm{RNA}$ copies $/ \mathrm{mL}$ & {$[194]$} \\
\hline Virus load under HAART & 50 RNA copies / mL & {$[57]$} \\
\hline Free virus half life in vivo (SIV) & $\sim 3-4 \min$ & {$[273]$} \\
\hline $\begin{array}{l}\text { Virus production per infected } \\
\text { cell }\end{array}$ & $5 \times 10^{4}$ & {$[43]$} \\
\hline Point mutation rate & $\begin{array}{l}2.2 \times 10^{-5}-5.4 \times 10^{-5} / \text { site } / \\
\text { cycle }\end{array}$ & {$[81,122,160,161]$} \\
\hline Recombination rate & $\begin{array}{l}1.4 \times 10^{-5}-3 \times 10^{-4} / \text { site } / \\
\text { cycle }\end{array}$ & {$[127,178,230,275]$} \\
\hline $\begin{array}{l}\text { Rate of HIV genetic diversity in- } \\
\text { crease in vivo } \mathbf{d}\end{array}$ & $1 \% /$ year in the envelope gene & {$[223]$} \\
\hline
\end{tabular}

b Dependent on virus and target cell

c Estimated from people under HAART

d Dependent on the genomic region

Table 3. Major aspects of HIV-host interaction and availability of mathematical models

\begin{tabular}{|lc|}
\hline Biological process & Availability of mathematical models \\
\hline Virus-target cell interaction & ++ \\
Innate response & + \\
Adaptive response (CTL) & ++ \\
Neutralizing Ab response & - \\
Virus evolution & +++ \\
Immune activation & - \\
Systemic regulation of immune homeostasis & - \\
Lymphoid tissue organization & - \\
Virus ontogeny in the target cell & - \\
Spatial dynamics of infection in a host & - \\
\hline
\end{tabular}

* The + and - signs refer to the relative abundance of models described in the literature. 
G. Bocharov, V. Chereshnev, I. Gainova, S. Bazhan, B. Bachmetyev, J. Argilaguet, J. Martinez, A. Meyerhans Human Immunodeficiency Virus Infection

Table 4. Details of existing frameworks for HIV infection modelling

\begin{tabular}{|c|c|c|c|c|}
\hline Processess & State space & Time scale & Nature of modelling & Ref. \\
\hline Viral evolution & $\begin{array}{l}\text { Wt virus, mutants, viral } \\
\text { genomes }\end{array}$ & $\begin{array}{l}\text { Short-, } \\
\text { long-term } \\
\text { dynamics }\end{array}$ & $\begin{array}{l}\text { Deterministic (ODEs, } \\
\text { Integro-DEs, hPDEs); } \\
\text { Stochastic (GA) } \\
\text { algorithms }\end{array}$ & $\begin{array}{l}{[26,66,150,} \\
182,255]\end{array}$ \\
\hline $\begin{array}{l}\text { Virus-target } \\
\text { cell dynamics }\end{array}$ & $\begin{array}{l}\text { Viral load, uninfected- } \\
\text { and infected- target } \\
\text { cells (naive, memory; } \\
\text { productively- and } \\
\text { latently infected, CD4 T } \\
\text { cells, APCs) }\end{array}$ & $\begin{array}{l}\text { Short-term } \\
\text { dynamics }\end{array}$ & $\begin{array}{l}\text { Deterministic (ODEs); } \\
\text { Stochastic (DEs) }\end{array}$ & $\begin{array}{l}{[2,132,182,} \\
189,269]\end{array}$ \\
\hline $\begin{array}{l}\text { Immune } \\
\text { responses }\end{array}$ & $\begin{array}{l}\text { CTLs, CD4 T cells, DCs, } \\
\text { NK cells, APCs }\end{array}$ & $\begin{array}{l}\text { Short-term } \\
\text { dynamics }\end{array}$ & $\begin{array}{l}\text { Deterministic (ODEs); } \\
\text { Stochastic (DEs) }\end{array}$ & $\begin{array}{l}{[49,119,182,} \\
208,240,261, \\
264]\end{array}$ \\
\hline $\begin{array}{l}\text { Whole infection: } \\
\text { from primary } \\
\text { phase to AIDS }\end{array}$ & $\begin{array}{l}\text { Virus, CD4 T cell, CTLs, } \\
\text { B cells, macrophages }\end{array}$ & $\begin{array}{l}\text { Long-term } \\
\text { dynamics }\end{array}$ & $\begin{array}{l}\text { Deterministic (ODEs, } \\
\text { hPDEs); Stochastic } \\
\text { (agent-based, hybrid) } \\
\text { models, DEs }\end{array}$ & $\begin{array}{l}{[40,76,106,} \\
120,182,185, \\
209,259]\end{array}$ \\
\hline
\end{tabular}

Acknowledgements. The research is supported by the grants from the Bill and Melinda Gates Foundation and the Spanish Ministry of Science and Innovation (SAF2010-21336), the Spanish Ministry of Education, Culture and Sports (SAB2011-0125), the program of the Russian Academy of Sciences "Basic Research for Medicine", the Russian Foundation for Basic Research (Grant 11-01-00117) and the Swedish Institute Visby Program "Adaptive Finite Element Methods for Solution of Inverse Problems" (project 2010-2013). We are most grateful to Christian Brander and Zvi Grossman for carefully reading the manuscript and providing valuable comments and conceptual proposals. We would also like to apologize for not being able to cite other interesting studies that also contributed to the topic described here.

\section{References}

[1] Q. Abdool Karim, S.S. Abdool Karim, J.A. Frohlich, A.C. Grobler, C. Baxter, L.E. Mansoor, A.B. Kharsany, S. Sibeko, K.P. Mlisana, Z. Omar, T.N. Gengiah, S. Maarschalk, N. Arulappan, M. Mlotshwa, L. Morris, D. Taylor. Effectiveness and safety of tenofovir gel, an antiretroviral microbicide, for the prevention of HIV infection in women. Science, 329(5996) (2010), 1168-74.

[2] B.M. Adams, H.T. Banks, M. Davidian, H.D. Kwon, H.T. Tran, S.N. Wynne, E.S. Rosenberg. HIV dynamics: Modeling, data analysis, and optimal treatment protocols. Journal of Computational and Applied Mathematics, 184 (2005), 10-49.

[3] B.M. Adams, H.T. Banks, M. Davidian, E.S. Rosenberg. Estimation and prediction with HIV-treatment interruption data. Bulletin of mathematical biology, 69 (2) (2007), 563-84.

[4] B.M. Adams, H.T. Banks, H.D. Kwon, H.T. Tran. Dynamic multidrug therapies for hiv: optimal and sti control approaches. Mathematical biosciences and engineering, 1 (2) (2004), 223-41.

[5] M. Alizon, S. Wain-Hobson, L. Montagnier, P. Sonigo. Genetic variability of the AIDS virus: nucleotide sequence analysis of two isolates from African patients. Cell, 46(1) (1986), 63-74.

[6] G. Alter, D. Heckerman, A. Schneidewind, L. Fadda, C.M. Kadie, J.M. Carlson, C. Oniangue-Ndza, M. Martin, B. Li, S. I. Khakoo, M. Carrington, T.M. Allen, M. Altfeld. HIV-1 adaptation to NK-cell-mediated immune pressure. Nature, 476(7358) (2011), 96-100. 
G. Bocharov, V. Chereshnev, I. Gainova, S. Bazhan, B. Bachmetyev, J. Argilaguet, J. Martinez, A. Meyerhans Human Immunodeficiency Virus Infection

[7] P. Arora, N.M. Dixit. Timing the emergence of resistance to anti-HIV drugs with large genetic barriers. PLoS computational biology, 5(3) (2009), p. e1000305.

[8] J. Arthos, C. Cicala, E. Martinelli, K. Macleod, D. Van Ryk, D. Wei, Z. Xiao, T.D. Veenstra, T.P. Conrad, R.A. Lempicki, S. McLaughlin, M. Pascuccio, R. Gopaul, J. McNally, C.C. Cruz, N. Censoplano, E. Chung, K.N. Reitano, S. Kottilil, D.J. Goode, A.S. Fauci. HIV-1 envelope protein binds to and signals through integrin alpha4beta7, the gut mucosal homing receptor for peripheral T cells. Nature immunology, 9(3) (2008), 301-9.

[9] E.J. Arts, D.J. Hazuda. HIV-1 Antiretroviral Drug Therapy. Cold Spring Harbor perspectives in medicine, 2(4) (2012), p. a007161.

[10] M.S.Ascher, H.W. Sheppard. AIDS as immune system activation: a model for pathogenesis. Clinical and experimental immunology, 73(2) (1988), 165-7.

[11] B. Asquith. The evolutionary selective advantage of HIV-1 escape variants and the contribution of escape to the HLA-associated risk of AIDS progression. PLoS One, 3(10) (2008), p. e3486.

[12] B. Asquith, C.T. Edwards, M. Lipsitch, A.R. McLean. Inefficient cytotoxic T lymphocyte-mediated killing of HIV-1infected cells in vivo. PLoS biology, 4(4) (2006), p. e90.

[13] B. Autran, G. Carcelain, T.S. Li, C. Blanc, D. Mathez, R. Tubiana, C. Katlama, P. Debre, J. Leibowitch. Positive effects of combined antiretroviral therapy on $C D_{4}+T$ cell homeostasis and function in advanced HIV disease. Science, 277(5322) (1997), 112-6.

[14] B. Auvert, D. Taljaard, E. Lagarde, J. Sobngwi-Tambekou, R. Sitta, A. Puren. Randomized, controlled intervention trial of male circumcision for reduction of HIV infection risk: the ANRS 1265 Trial. PLoS medicine, 2(11) (2005), p. e298.

[15] E. Baake. Mutation and recombination with tight linkage. Journal of mathematical biology, 42(5) (2001), 455-88.

[16] R.C. Bailey, S. Moses, C.B. Parker, K. Agot, I. Maclean, J.N. Krieger, C.F. M. Williams, R.T. Campbell, J.O. NdinyaAchola. Male circumcision for HIV prevention in young men in Kisumu, Kenya: a randomised controlled trial. Lancet, 369(9562) (2007), 643-56.

[17] H.T. Banks, M. Davidian, S. Hu, G.M. Kepler, E.S. Rosenberg. Modeling HIV Immune Response and Validation with Clinical Data. Journal of biological dynamics, 2(4) (2008), 357-85.

[18] H.T. Banks, H.-D. Kwon, J.A. Toivanen, H.T. Tran. A state-dependent Riccati equation-based estimator approach for HIV feedback control. Optim. Control Appl. Meth., 27(2006), 93-121.

[19] D.L. Barber, E.J. Wherry, D. Masopust, B. Zhu, J.P. Allison, A. H. Sharpe, G.J. Freeman, R. Ahmed. Restoring function in exhausted CD8 T cells during chronic viral infection. Nature, 439(7077) (2006), 682-7.

[20] F. Barre-Sinoussi, J.C. Chermann, F. Rey, M.T. Nugeyre, S. Chamaret, J. Gruest, C. Dauguet, C. Axler-Blin, F. Vezinet-Brun, C. Rouzioux, W. Rozenbaum, L. Montagnier. Isolation of a T-lymphotropic retrovirus from a patient at risk for acquired immune deficiency syndrome (AIDS). Science, 220(4599) (1983), 868-71.

[21] R. Batorsky, M.F. Kearney, S.E. Palmer, F. Maldarelli, I.M. Rouzine, J.M. Coffin. Estimate of effective recombination rate and average selection coefficient for HIV in chronic infection. Proceedings of the National Academy of Sciences of the United States of America, 108(14) (2011), 5661-6.

[22] V. Baumgartel, S. Ivanchenko, A. Dupont, M. Sergeev, P.W. Wiseman, H.G. Krausslich, C. Brauchle, B. Muller, D.C. Lamb. Live-cell visualization of dynamics of HIV budding site interactions with an ESCRT component. Nature cell biology, 13(4) (2011), 469-74.

[23] G. Bello, C.A. Velasco-de-Castro, V. Bongertz, C.A. Rodrigues, C.B. Giacoia-Gripp, J.H. Pilotto, B. Grinsztejn, V.G. Veloso, M.G. Morgado. Immune activation and antibody responses in non-progressing elite controller individuals infected with $H I V-1$. Journal of medical virology, 81(10) (2009), 1681-90.

[24] Z. Bentwich, A. Kalinkovich, Z. Weisman, Z. Grossman. Immune activation in the context of HIV infection. Clinical and experimental immunology, 111(1) (1998), 1-2.

[25] E. Berntorp, A.D. Shapiro. Modern haemophilia care. Lancet, 379(9824) (2012), 1447-56.

[26] G. Bocharov, N.J. Ford, J. Edwards, T. Breinig, S. Wain-Hobson, A. Meyerhans. A genetic-algorithm approach to simulating human immunodeficiency virus evolution reveals the strong impact of multiply infected cells and recombination. The Journal of general virology, 86(Pt 11) (2005), 3109-18.

[27] M.C. Boily, R.F. Baggaley, L. Wang, B. Masse, R.G. White, R.J. Hayes, M. Alary. Heterosexual risk of HIV-1 infection per sexual act: systematic review and meta-analysis of observational studies. The Lancet infectious diseases, 9(2) (2009), 118-29.

[28] J. Bongaarts, P. Reining, P. Way, F. Conant. The relationship between male circumcision and HIV infection in African populations. AIDS, 3(6) (1989), 373-7.

[29] P. Borrow. Innate immunity in acute HIV-1 infection. Current opinion in HIV and AIDS, 6(5) (2011), 353-63.

[30] S.E. Bosinger, Q. Li, S.N. Gordon, N.R. Klatt, L. Duan, L. Xu, N. Francella, A. Sidahmed, A.J. Smith, E.M. Cramer, M. Zeng, D. Masopust, J.V. Carlis, L. Ran, T.H. Vanderford, M. Paiardini, R.B. Isett, D.A. Baldwin, J.G. Else, S.I. Staprans, G. Silvestri, A.T. Haase, D.J. Kelvin. Global genomic analysis reveals rapid control of a robust innate response in SIV-infected sooty mangabeys. The Journal of clinical investigation, 119(12) (2009), 3556-72.

[31] S. Bouchat, J. S. Gatot, K. Kabeya, C. Cardona, L. Colin, G. Herbein, S. de Wit, N. Clumeck, O. Lambotte, C. Rouzioux, O. Rohr, C. van Lint. Histone methyltransferase inhibitors induce HIV-1 recovery in resting CD4+T cells from HIV-1+ HAART-treated patients. AIDS, (2012).

[32] A.L. Brass, D.M. Dykxhoorn, Y. Benita, N. Yan, A. Engelman, R.J. Xavier, J. Lieberman, S.J. Elledge. Identification of host proteins required for HIV infection through a functional genomic screen. Science, 319(5865) (2008), 921-6. 
G. Bocharov, V. Chereshnev, I. Gainova, S. Bazhan, B. Bachmetyev, J. Argilaguet, J. Martinez, A. Meyerhans Human Immunodeficiency Virus Infection

[33] J.M. Brenchley, D.A. Price, T.W. Schacker, T.E. Asher, G. Silvestri, S. Rao, Z. Kazzaz, E. Bornstein, O. Lambotte, D. Altmann, B.R. Blazar, B. Rodriguez, L. Teixeira-Johnson, A. Landay, J.N. Martin, F.M. Hecht, L.J. Picker, M.M. Lederman, S.G. Deeks, D.C. Douek. Microbial translocation is a cause of systemic immune activation in chronic HIV infection. Nature medicine, 12(12) (2006), 1365-71.

[34] J.M. Brenchley, T.W. Schacker, L.E. Ruff, D.A. Price, J.H. Taylor, G.J. Beilman, P.L. Nguyen, A. Khoruts, M. Larson, A.T. Haase, D.C. Douek. CD4 $+T$ cell depletion during all stages of HIV disease occurs predominantly in the gastrointestinal tract. The Journal of experimental medicine, 200(6) (2004), 749-59.

[35] J.E Brinchmann, J. Albert, F. Vartdal. Few infected CD4+T cells but a high proportion of replication-competent provirus copies in asymptomatic human immunodeficiency virus type 1 infection. Journal of virology, 65(4) (1991), 2019-23.

[36] A.J. Brown. Analysis of HIV-1 env gene sequences reveals evidence for a low effective number in the viral population. Proceedings of the National Academy of Sciences of the United States of America, 94(5) (1997), 1862-5.

[37] F. Brun-Vezinet, C. Rouzioux, F. Barre-Sinoussi, D. Klatzmann, A.G. Saimot, W. Rozenbaum, D. Christol, J.C. Gluckmann, L. Montagnier, J.C. Chermann. Detection of $I g G$ antibodies to lymphadenopathy-associated virus in patients with AIDS or lymphadenopathy syndrome. Lancet, 1(8389) (1984), 1253-6.

[38] S.P. Buchbinder, D.V. Mehrotra, A. Duerr, D.W. Fitzgerald, R. Mogg, D. Li, P.B. Gilbert, J.R. Lama, M. Marmor, C. Del Rio, M.J. McElrath, D.R. Casimiro, K.M. Gottesdiener, J.A. Chodakewitz, L. Corey, M.N. Robertson. Efficacy assessment of a cell-mediated immunity HIV-1 vaccine (the Step Study): a double-blind, randomised, placebo-controlled, test-of-concept trial. Lancet, 372(9653) (2008), 1881-93.

[39] F.D. Bushman, N. Malani, J. Fernandes, I. D’Orso, G. Cagney, T.L. Diamond, H. Zhou, D.J. Hazuda, A.S. Espeseth, R. Konig, S. Bandyopadhyay, T. Ideker, S.P. Goff, N.J. Krogan, A.D. Frankel, J.A. Young, S.K. Chanda. Host cell factors in HIV replication: meta-analysis of genome-wide studies. PLoS pathogens, 5(5) (2009), p. e1000437.

[40] M.A. Capistran. A study of latency, reactivation and apoptosis throughout HIV pathogenesis. Mathematical \& Computer Modelling, 52(2010), 1011-5.

[41] M. Cavrois, J. Neidleman, J.F. Kreisberg, W. C. Greene. In vitro derived dendritic cells trans-infect CD4 T cells primarily with surface-bound HIV-1 virions. PLoS pathogens, 3(1) (2007), p. e4.

[42] M. Centlivre, M. Sala, S. Wain-Hobson, B. Berkhout. In HIV-1 pathogenesis the die is cast during primary infection. AIDS, 21(1) (2007), 1-11.

[43] H.Y. Chen, M. Di Mascio, A.S. Perelson, D.D. Ho, L. Zhang. Determination of virus burst size in vivo using a singlecycle SIV in rhesus macaques. Proceedings of the National Academy of Sciences of the United States of America, 104(48) (2007), 19079-84.

[44] C. Cheng-Mayer, M. Quiroga, J.W. Tung, D. Dina, J.A. Levy. Viral determinants of human immunodeficiency virus type 1 T-cell or macrophage tropism, cytopathogenicity, and CD4 antigen modulation. Journal of virology, 64(9) (1990), $4390-8$

[45] S.K. Choudhary, N. Vrisekoop, C.A. Jansen, S.A. Otto, H. Schuitemaker, F. Miedema, D. Camerini. Low immune activation despite high levels of pathogenic human immunodeficiency virus type 1 results in long-term asymptomatic disease. Journal of virology, 81(16) (2007), 8838-42.

[46] T.W. Chun, K. Chadwick, J. Margolick, R.F. Siliciano. Differential susceptibility of naive and memory CD4+ T cells to the cytopathic effects of infection with human immunodeficiency virus type 1 strain LAI. Journal of virology, 71(6) (1997), 4436-44.

[47] T.W. Chun, D. Finzi, J. Margolick, K. Chadwick, D. Schwartz, R.F. Siliciano. In vivo fate of HIV-1-infected T cells: quantitative analysis of the transition to stable latency. Nature medicine, 1(12) (1995), 1284-90.

[48] C. Cicala, E. Martinelli, J.P. McNally, D.J. Goode, R. Gopaul, J. Hiatt, K. Jelicic, S. Kottilil, K. Macleod, A. O'Shea, N. Patel, D. Van Ryk, D. Wei, M. Pascuccio, L. Yi, L. McKinnon, P. Izulla, J. Kimani, R. Kaul, A.S. Fauci, J. Arthos. The integrin alpha4beta7 forms a complex with cell-surface CD4 and defines a T-cell subset that is highly susceptible to infection by HIV-1. Proceedings of the National Academy of Sciences of the United States of America, 106(49) (2009), $20877-82$.

[49] M.S. Ciupe, B.L. Bivort, D.M. Bortz, P.W. Nelson. Estimating kinetic parameters from HIV primary infection data through the eyes of three different mathematical models. Mathematical biosciences, 200(1) (2006), 1-27.

[50] F. Clavel, D. Guetard, F. Brun-Vezinet, S. Chamaret, M.A. Rey, M.O. Santos-Ferreira, A.G. Laurent, C. Dauguet, C. Katlama, C. Rouzioux, and et al. Isolation of a new human retrovirus from West African patients with AIDS. Science, 233(4761) (1986), 343-6.

[51] F. Clayton, G. Snow, S. Reka, D.P. Kotler. Selective depletion of rectal lamina propria rather than lymphoid aggregate CD4 lymphocytes in HIV infection. Clinical and experimental immunology, 107(2) (1997), 288-92.

[52] F. Cocchi, A.L. DeVico, A. Garzino-Demo, A. Cara, R.C. Gallo, P. Lusso. The V3 domain of the HIV-1 gp120 envelope glycoprotein is critical for chemokine-mediated blockade of infection. Nature medicine, 2(11) (1996), $1244-7$.

[53] J.M. Coffin. Structure, replication, and recombination of retrovirus genomes: some unifying hypotheses. The Journal of general virology, 42(1) (1979), 1-26.

[54] J. Cohen. Understanding HIV latency to undo it. Science, 332(6031) (2011), 786.

[55] M.S. Cohen, Y.Q. Chen, M. McCauley, T. Gamble, M.C. Hosseinipour, N. Kumarasamy, J.G. Hakim, J. Kumwenda, B. Grinsztejn, J.H. Pilotto, S.V. Godbole, S. Mehendale, S. Chariyalertsak, B.R. Santos, K.H. Mayer, I.F. Hoffman, S.H. Eshleman, E. Piwowar-Manning, L. Wang, J. Makhema, L.A. Mills, G. de Bruyn, I. Sanne, J. Eron, J. Gallant, D. Havlir, S. Swindells, H. Ribaudo, V. Elharrar, D. Burns, T.E. Taha, K. Nielsen-Saines, D. Celentano, M. Essex, T.R. Fleming. Prevention of HIV-1 infection with early antiretroviral therapy. The New England journal of medicine, 365(6) (2011), 493-505. 
G. Bocharov, V. Chereshnev, I. Gainova, S. Bazhan, B. Bachmetyev, J. Argilaguet, J. Martinez, A. Meyerhans Human Immunodeficiency Virus Infection

[56] J.W Cohen Stuart, M.D. Hazebergh, D. Hamann, S.A. Otto, J.C. Borleffs, F. Miedema, C.A. Boucher, R.J. de Boer. The dominant source of $C D 4+$ and $C D 8+T$-cell activation in HIV infection is antigenic stimulation. AIDS, 25(3) (2000), 203-11.

[57] A.C. Collier, R.W. Coombs, D. A. Schoenfeld, R.L. Bassett, J. Timpone, A. Baruch, M. Jones, K. Facey, C. Whitacre, V.J. McAuliffe, H.M. Friedman, T.C. Merigan, R. C. Reichman, C. Hooper, L. Corey. Treatment of human immunodeficiency virus infection with saquinavir, zidovudine, and zalcitabine. AIDS Clinical Trials Group. he New England journal of medicine, 334(16) (1996), 1011-7.

[58] R. Collman, N.F. Hassan, R. Walker, B. Godfrey, J. Cutilli, J.C. Hastings, H. Friedman, S.D. Douglas, N. Nathanson. Infection of monocyte-derived macrophages with human immunodeficiency virus type 1 (HIV-1). Monocyte-tropic and lymphocyte-tropic strains of $H I V-1$ show distinctive patterns of replication in a panel of cell types. The Journal of experimental medicine, 170(4) (1989), 1149-63.

[59] M.P. D'Souza, V.A. Harden. Chemokines and HIV-1 second receptors. Confluence of two fields generates optimism in AIDS research. Nature medicine, 2(12) (1996), 1293-300.

[60] A.G. Dalgleish, P.C. Beverley, P.R. Clapham, D.H. Crawford, M.F. Greaves, R.A. Weiss. The CD4 (T4) antigen is an essential component of the receptor for the AIDS retrovirus. Nature, 312(5996) (1984), 763-7.

[61] J. David, H. Tran, H.T. Banks. HIV model analysis and estimation implementation under optimal control based treatment strategies. Int. J. Pure Appl. Math., 57(2009), 357-92.

[62] C.L. Day, D.E. Kaufmann, P. Kiepiela, J.A. Brown, E.S. Moodley, S. Reddy, E.W. Mackey, J.D. Miller, A.J. Leslie, C. DePierres, Z. Mncube, J. Duraiswamy, B. Zhu, Q. Eichbaum, M. Altfeld, E.J. Wherry, H.M. Coovadia, P.J. Goulder, P. Klenerman, R. Ahmed, G.J. Freeman, B.D. Walker. PD-1 expression on HIV-specific T cells is associated with T-cell exhaustion and disease progression. Nature, 443(7109) (2006), 350-4.

[63] R.J. De Boer, R.M. Ribeiro, A.S. Perelson. Current estimates for HIV-1 production imply rapid viral clearance in lymphoid tissues. PLoS computational biology, 6(9) (2010), p. e1000906.

[64] M. De Martino, P.A. Tovo, A.E. Tozzi, P. Pezzotti, L. Galli, S. Livadiotti, D. Caselli, E. Massironi, E. Ruga, F. Fioredda. HIV-1 transmission through breast-milk: appraisal of risk according to duration of feeding. AIDS (London, England), 6(9) (1992), 991.

[65] S.G. Deeks, C.M. Kitchen, L. Liu, H. Guo, R. Gascon, A.B. Narvaez, P. Hunt, J.N. Martin, J.O. Kahn, J. Levy, M.S. McGrath, F.M. Hecht. Immune activation set point during early HIV infection predicts subsequent CD4+T-cell changes independent of viral load. Blood, 104(4) (2004), 942-7.

[66] N.M. Dixit, A. S. Perelson. HIV dynamics with multiple infections of target cells. Proceedings of the National Academy of Sciences of the United States of America, 102(23) (2005), 8198-203.

[67] D. Donnell, J.M. Baeten, J. Kiarie, K.K. Thomas, W. Stevens, C.R. Cohen, J. McIntyre, J.R. Lingappa, C. Celum. Heterosexual HIV-1 transmission after initiation of antiretroviral therapy: a prospective cohort analysis. Lancet, 375(9731) (2010), 2092-8.

[68] D. Douek. HIV disease progression: immune activation, microbes, and a leaky gut. Topics in HIV medicine: a publication of the International AIDS Society, USA, 15(4) (2007), 114-7.

[69] T. Dragic, V. Litwin, G.P. Allaway, S.R. Martin, Y. Huang, K.A. Nagashima, C. Cayanan, P.J. Maddon, R.A. Koup, J.P. Moore, W.A. Paxton. HIV-1 entry into CD4+ cells is mediated by the chemokine receptor CC-CKR-5. Nature, 381(6584) (1996), 667-73.

[70] J. Embretson, M. Zupancic, J.L. Ribas, A. Burke, P. Racz, K. Tenner-Racz, A.T. Haase. Massive covert infection of helper T lymphocytes and macrophages by HIV during the incubation period of AIDS. Nature, 362(6418) (1993), 359-62.

[71] A. Engelman, P. Cherepanov. The structural biology of HIV-1: mechanistic and therapeutic insights. Nature reviews. Microbiology, 10(4) (2012), 279-90.

[72] A.S. Fauci, H.C. Lane. A Preventive Vaccine Against HIV Infection. Harrison's Principles of Internal Medicine, (2012), $18 \mathrm{e}$.

[73] D. Favre, S. Lederer, B. Kanwar, Z.M. Ma, S. Proll, Z. Kasakow, J. Mold, L. Swainson, J.D. Barbour, C.R. Baskin, R. Palermo, I. Pandrea, C.J. Miller, M.G. Katze, J. M. McCune. Critical loss of the balance between Th17 and T regulatory cell populations in pathogenic SIV infection. PLoS pathogens, 5(2) (2009), p. e1000295.

[74] N.M. Ferguson, F. deWolf, A.C. Ghani, C. Fraser, C.A. Donnelly, P. Reiss, J.M. Lange, S.A. Danner, G.P. Garnett, J. Goudsmit, R.M. Anderson. Antigen-driven CD4 $+T$ cell and HIV-1 dynamics: residual viral replication under highly active antiretroviral therapy. Proceedings of the National Academy of Sciences of the United States of America, 96(26) (1999), 15167-72.

[75] D. Finzi, J. Blankson, J.D. Siliciano, J.B. Margolick, K. Chadwick, T. Pierson, K. Smith, J. Lisziewicz, F. Lori, C. Flexner, T.C. Quinn, R.E. Chaisson, E. Rosenberg, B. Walker, S. Gange, J. Gallant, R. F. Siliciano. Latent infection of $C_{4}+T$ cells provides a mechanism for lifelong persistence of $H I V-1$, even in patients on effective combination therapy. Nature medicine, 5(5) (1999), 512-7.

[76] C. Fraser, N.M. Ferguson, F. de Wolf, R.M. Anderson. The role of antigenic stimulation and cytotoxic T cell activity in regulating the long-term immunopathogenesis of HIV: mechanisms and clinical implications. Proceedings. Biological sciences / The Royal Society, 268(1481) (2001), 2085-95.

[77] S.D. Frost, M.J. Dumaurier, S. Wain-Hobson, A.J. Brown. Genetic drift and within-host metapopulation dynamics of $H I V-1$ infection. Proceedings of the National Academy of Sciences of the United States of America, 98(12) (2001), 6975-80.

[78] R.C. Gallo, S.Z. Salahuddin, M. Popovic, G.M. Shearer, M. Kaplan, B.F. Haynes, T.J. Palker, R. Redfield, J. Oleske, B. Safai, and et al. Frequent detection and isolation of cytopathic retroviruses (HTLV-III) from patients with AIDS and at risk for AIDS. Science, 224(4648) (1984), 500-3. 
G. Bocharov, V. Chereshnev, I. Gainova, S. Bazhan, B. Bachmetyev, J. Argilaguet, J. Martinez, A. Meyerhans Human Immunodeficiency Virus Infection

[79] V.V. Ganusov, R.J. De Boer. Do most lymphocytes in humans really reside in the gut? Trends in immunology, 28(12) (2007), 514-8.

[80] V.V. Ganusov, N. Goonetilleke, M.K. Liu, G. Ferrari, G.M. Shaw, A.J. McMichael, P. Borrow, B.T. Korber, A.S. Perelson. Fitness costs and diversity of the cytotoxic T lymphocyte (CTL) response determine the rate of CTL escape during acute and chronic phases of HIV infection. Journal of virology, 85(20) (2011), 10518-28.

[81] F. Gao, Y. Chen, D.N. Levy, J.A. Conway, T.B. Kepler, H. Hui. Unselected mutations in the human immunodeficiency virus type 1 genome are mostly nonsynonymous and often deleterious. Journal of virology, 78(5) (2004), 2426-33.

[82] E. Garcia, M. Pion, A. Pelchen-Matthews, L. Collinson, J.F. Arrighi, G. Blot, F. Leuba, J.M. Escola, N. Demaurex, M. Marsh, V. Piguet. HIV-1 trafficking to the dendritic cell-T-cell infectious synapse uses a pathway of tetraspanin sorting to the immunological synapse. Traffic, 6(6) (2005), 488-501.

[83] T.B. Geijtenbeek, D.S. Kwon, R. Torensma, S.J. van Vliet, G.C. van Duijnhoven, J. Middel, I.L. Cornelissen, H.S. Nottet, V.N. KewalRamani, D.R. Littman, C.G. Figdor, Y. van Kooyk. DC-SIGN, a dendritic cell-specific HIV-1binding protein that enhances trans-infection of T cells. Cell, 100(5) (2000), 587-97.

[84] C. Geldmacher, J.R. Currier, E. Herrmann, A. Haule, E. Kuta, F. McCutchan, L. Njovu, S. Geis, O. Hoffmann, L. Maboko, C. Williamson, D. Birx, A. Meyerhans, J. Cox, M. Hoelscher. CD8 T-cell recognition of multiple epitopes within specific Gag regions is associated with maintenance of a low steady-state viremia in human immunodeficiency virus type 1-seropositive patients. Journal of virology, 81(5) (2007), 2440-8.

[85] H.E. Gendelman, L.M. Baca, H. Husayni, J.A. Turpin, D. Skillman, D.C. Kalter, J.M. Orenstein, D.L. Hoover, M.S. Meltzer. Macrophage-HIV interaction: viral isolation and target cell tropism. AIDS, 4(3) (1990), 221-8.

[86] J.V. Giorgi, L.E. Hultin, J.A. McKeating, T.D. Johnson, B. Owens, L.P. Jacobson, R. Shih, J. Lewis, D.J. Wiley, J.P. Phair, S.M. Wolinsky, R. Detels. Shorter survival in advanced human immunodeficiency virus type 1 infection is more closely associated with $T$ lymphocyte activation than with plasma virus burden or virus chemokine coreceptor usage. The Journal of infectious diseases, 179(4) (1999), 859-70.

[87] D. Gisselquist, G. Upham, J.J. Potterat. Efficiency of human immunodeficiency virus transmission through injections and other medical procedures: evidence, estimates, and unfinished business. Infection control and hospital epidemiology: The official journal of the Society of Hospital Epidemiologists of America, 27(9) (2006), 944-52.

[88] M. Goodenow, T. Huet, W. Saurin, S. Kwok, J. Sninsky, S. Wain-Hobson. HIV-1 isolates are rapidly evolving quasispecies: evidence for viral mixtures and preferred nucleotide substitutions. J. Acquir. Immune Defic. Syndr., 2(4) (1989), 344-52.

[89] N. Goonetilleke, M.K. Liu, J.F. Salazar-Gonzalez, G. Ferrari, E. Giorgi, V.V. Ganusov, B.F. Keele, G.H. Learn, E.L. Turnbull, M.G. Salazar, K.J. Weinhold, S. Moore, N. Letvin, B.F. Haynes, M.S. Cohen, P. Hraber, T. Bhattacharya, P. Borrow, A.S. Perelson, B.H. Hahn, G.M. Shaw, B.T. Korber, A.J. McMichael. The first T cell response to transmitted/founder virus contributes to the control of acute viremia in $H I V-1$ infection. Journal of experimental medicine, 206(6) (2009), 1253-72.

[90] M.S. Gottlieb, R. Schroff, H.M. Schanker, J.D. Weisman, P.T. Fan, R.A. Wolf, A. Saxon. Pneumocystis carinii pneumonia and mucosal candidiasis in previously healthy homosexual men: evidence of a new acquired cellular immunodeficiency. The New England journal of medicine, 305(24) (1981), 1425-31.

[91] P.J. Goulder, D.I. Watkins. HIV and SIV CTL escape: implications for vaccine design. Nature reviews. Immunology, $4(8)$ (2004), 630-40.

[92] R.M. Grant, J.R. Lama, P.L. Anderson, V. McMahan, A.Y. Liu, L. Vargas, P. Goicochea, M. Casapia, J.V. GuaniraCarranza, M.E. Ramirez-Cardich, O. Montoya-Herrera, T. Fernandez, V.G. Veloso, S.P. Buchbinder, S. Chariyalertsak, M. Schechter, L.G. Bekker, K.H. Mayer, E.G. Kallas, K.R. Amico, K. Mulligan, L.R. Bushman, R.J. Hance, C. Ganoza, P. Defechereux, B. Postle, F. Wang, J.J. McConnell, J.H. Zheng, J. Lee, J.F. Rooney, H.S. Jaffe, A.I. Martinez, D.N. Burns, D.V. Glidden. Preexposure chemoprophylaxis for HIV prevention in men who have sex with men. The New England journal of medicine, 363(27) (2010), 2587-99.

[93] R.H. Gray, M.J. Wawer, R. Brookmeyer, N.K. Sewankambo, D. Serwadda, F. Wabwire-Mangen, T. Lutalo, X. Li, T. vanCott, T.C. Quinn. Probability of HIV-1 transmission per coital act in monogamous, heterosexual, HIV-1-discordant couples in Rakai, Uganda. Lancet, 357(9263) (2001), 1149-53.

[94] F. Groot, T.M. van Capel, J. Schuitemaker, B. Berkhout, E.C. de Jong. Differential susceptibility of naive, central memory and effector memory $T$ cells to dendritic cell-mediated HIV-1 transmission. Retrovirology, 3(2006), 52.

[95] Z. Grossman. Mathematical modeling of thymopoiesis in HIV infection: real data, virtual data, and data interpretation. Clin. Immunol., 107(3) (2003), 137-9.

[96] Z. Grossman, M.B. Feinberg, W.E. Paul. Multiple modes of cellular activation and virus transmission in HIV infection: a role for chronically and latently infected cells in sustaining viral replication. Proceedings of the National Academy of Sciences of the United States of America, 95(11) (1998), 6314-9.

[97] Z. Grossman, M. Meier-Schellersheim, W.E. Paul, L.J. Picker. Pathogenesis of HIV infection: what the virus spares is as important as what it destroys. Nature medicine, 12(3) (2006), 289-95.

[98] Z. Grossman, M. Meier-Schellersheim, A. E. Sousa, R. M. Victorino, and W. E. Paul. CD4+ T-cell depletion in HIV infection: are we closer to understanding the cause? Nature medicine, 8(4) (2002), 319-23.

[99] Z. Grossman, B. Min, M. Meier-Schellersheim, W. E. Paul. Concomitant regulation of T-cell activation and homeostasis. Nature reviews. Immunology, 4(5) (2004), 387-95.

[100] Z. Grossman, W.E. Paul. The impact of HIV on naive T-cell homeostasis. Nature medicine, 6(9) (2000), 976-7.

[101] Z. Grossman, L. J. Picker. Pathogenic mechanisms in simian immunodeficiency virus infection. CCurrent opinion in HIV and AIDS, 3(3) (2008), 380-6. 
G. Bocharov, V. Chereshnev, I. Gainova, S. Bazhan, B. Bachmetyev, J. Argilaguet, J. Martinez, A. Meyerhans Human Immunodeficiency Virus Infection

[102] L.A. Guay, P. Musoke, T. Fleming, D. Bagenda, M. Allen, C. Nakabiito, J. Sherman, P. Bakaki, C. Ducar, M. Deseyve, L. Emel, M. Mirochnick, M. G. Fowler, L. Mofenson, P. Miotti, K. Dransfield, D. Bray, F. Mmiro, J.B. Jackson. Intrapartum and neonatal single-dose nevirapine compared with zidovudine for prevention of mother-to-child transmission of HIV-1 in Kampala, Uganda: HIVNET 012 randomised trial. Lancet, 354(9181), (1999), 795-802.

[103] M. Guyader, M. Emerman, P. Sonigo, F. Clavel, L. Montagnier, M. Alizon. Genome organization and transactivation of the human immunodeficiency virus type 2. Nature, 326(6114) (1987), 662-9.

[104] A.T. Haase. Population biology of HIV-1 infection: viral and CD $4+T$ cell demographics and dynamics in lymphatic tissues. Annual review of immunology, 17(1999), 625-56.

[105] A.T. Haase. Targeting early infection to prevent HIV-1 mucosal transmission. Nature, 464(7286) (2010), $217-23$.

[106] M. Hadjiandreou, R. Conejeros, V.S. Vassiliadis. Towards a long-term model construction for the dynamic simulation of HIV infection. Mathematical biosciences and engineering, 4(3) (2007), 489-504.

[107] M. Hadjiandreou, R. Conejeros, J. Wilson. HIV treatment planning on a case-by-case basis. International Journal of Biological and Life Sciences, 7 (2011), 148-57.

[108] B.H. Hahn, G.M. Shaw, M.E. Taylor, R.R. Redfield, P.D. Markham, S.Z. Salahuddin, F. Wong-Staal, R.C. Gallo, E.S. Parks, W.P. Parks. Genetic variation in HTLV-III/LAV over time in patients with AIDS or at risk for AIDS. Science, 232(4757) (1986), 1548-53.

[109] R.S. Harris, K.N. Bishop, A.M. Sheehy, H.M. Craig, S.K. Petersen-Mahrt, I.N. Watt, M.S. Neuberger, M.H. Malim. DNA deamination mediates innate immunity to retroviral infection. Cell, 113(6) (2003), 803-9.

[110] B.F. Haynes, P.B. Gilbert, M.J. McElrath, S. Zolla-Pazner, G.D. Tomaras, S.M. Alam, D.T. Evans, D.C. Montefiori, C. Karnasuta, R. Sutthent, H.X. Liao, A.L. DeVico, G.K. Lewis, C. Williams, A. Pinter, Y. Fong, H. Janes, A. DeCamp, Y. Huang, M. Rao, E. Billings, N. Karasavvas, M.L. Robb, V. Ngauy, M.S. de Souza, R. Paris, G. Ferrari, R.T. Bailer, K.A. Soderberg, C. Andrews, P.W. Berman, N. Frahm, S.C. De Rosa, MD. Alpert, N. L. Yates, X. Shen, R.A. Koup, P. Pitisuttithum, J. Kaewkungwal, S. Nitayaphan, S. Rerks-Ngarm, N.L. Michael, J.H. Kim. Immune-correlates analysis of an HIV-1 vaccine efficacy trial. The New England journal of medicine, 366(14) (2012), 1275-86.

[111] M.D. Hazenberg, S.A. Otto, J.W. Cohen Stuart, M.C. Verschuren, J.C. Borleffs, C.A. Boucher, R.A. Coutinho, J.M. Lange, T.F. Rinke de Wit, A. Tsegaye, J.J. van Dongen, D. Hamann, R.J. de Boer, F. Miedema. Increased cell division but not thymic dysfunction rapidly affects the $T$-cell receptor excision circle content of the naive $T$ cell population in HIV-1 infection. Nature medicine, 6(9) (2000), 1036-42.

[112] M.D. Hazenberg, S. A. Otto, B.H. van Benthem, M.T. Roos, R.A. Coutinho, J.M. Lange, D. Hamann, M. Prins, F. Miedema. Persistent immune activation in HIV-1 infection is associated with progression to AIDS. AIDS, 17(13) (2003), 1881-8.

[113] M.D. Hazenberg, J.W. Stuart, S.A. Otto, J.C. Borleffs, C.A. Boucher, R.J. de Boer, F. Miedema, D. Hamann. Tcell division in human immunodeficiency virus (HIV)-1 infection is mainly due to immune activation: a longitudinal analysis in patients before and during highly active antiretroviral therapy (HAART). Blood, 95(1) (2000), $249-55$.

[114] S.L. Heath, J.G. Tew, J.G. Tew, A.K. Szakal, G.F. Burton. Follicular dendritic cells and human immunodeficiency virus infectivity. Nature, 377(6551) (1995), 740-4.

[115] M. Hellerstein, M.B. Hanley, D. Cesar, S. Siler, C. Papageorgopoulos, E. Wieder, D. Schmidt, R. Hoh, R. Neese, D. Macallan, S. Deeks, J.M. McCune. Directly measured kinetics of circulating T lymphocytes in normal and HIV-1infected humans. Nature medicine, 5(1) (1999), 83-9.

[116] J.T Herbeck, M. Rolland, Y. Liu, S. McLaughlin, J. McNevin, H. Zhao, K. Wong, J.N. Stoddard, D. Raugi, S. Sorensen, I. Genowati, B. Birditt, A. McKay, K. Diem, B.S. Maust, W. Deng, A.C. Collier, J.D. Stekler, M.J. McElrath, J.I. Mullins. Demographic processes affect HIV-1 evolution in primary infection before the onset of selective processes. Journal of virology, 85(15) (2011), 7523-34.

[117] E.A. Hernandez-Vargas, D. Mehta, R.H. Middleton. Towards Modelling HIV Long Term Behavior. Preprints of the 18th IFAC World Congress, (2011), 581-6.

[118] D.D. Ho, A.U. Neumann, A.S. Perelson, W. Chen, J.M. Leonard, M. Markowitz. Rapid turnover of plasma virions and CD4 lymphocytes in HIV-1 infection. Nature, 373(6510) (1995), 123-6.

[119] I.B. Hogue, S.H. Bajaria, B.A. Fallert, S. Qin, T.A. Reinhart, D.E. Kirschner. The dual role of dendritic cells in the immune response to human immunodeficiency virus type 1 infection. The Journal of general virology, 89(2008), $2228-39$.

[120] T. Hraba, J. Dolezal. A mathematical model and CD4+ lymphocyte dynamics in HIV infection. Emerging infectious diseases, 2(4) (1996), 299-305.

[121] K. Hrecka, C. Hao, M. Gierszewska, S.K. Swanson, M. Kesik-Brodacka, S. Srivastava, L. Florens, M.P. Washburn, J. Skowronski. Vpx relieves inhibition of HIV-1 infection of macrophages mediated by the SAMHD1 protein. Nature, 474(7353) (2011), 658-61.

[122] K.J. Huang, D.P. Wooley. A new cell-based assay for measuring the forward mutation rate of HIV-1. Journal of virological methods, 124(1-2) (2005), 95-104.

[123] S.S. Hwang, T.J. Boyle, H.K. Lyerly, B.R. Cullen. Identification of the envelope V3 loop as the primary determinant of cell tropism in HIV-1. Science, 253(5015) (1991), 71-4.

[124] N. Izquierdo-Useros, M. Lorizate, F.X. Contreras, M.T. Rodriguez-Plata, B. Glass, I. Erkizia, J.G. Prado, J. Casas, G. Fabrias, H.G. Krausslich, J. Martinez-Picado. Sialyllactose in Viral Membrane Gangliosides Is a Novel Molecular Recognition Pattern for Mature Dendritic Cell Capture of HIV-1. PLoS biology, 10(4) (2012), p. e1001315.

[125] B. Jacquelin, V. Mayau, B. Targat, A.S. Liovat, D. Kunkel, G. Petitjean, M. A. Dillies, P. Roques, C. Butor, G. Silvestri, L.D. Giavedoni, P. Lebon, F. Barre-Sinoussi, A. Benecke, M.C. Muller-Trutwin. Nonpathogenic SIV infection of African green monkeys induces a strong but rapidly controlled type I IFN response. The Journal of clinical investigation, 119(12) (2009), 3544-55. 
G. Bocharov, V. Chereshnev, I. Gainova, S. Bazhan, B. Bachmetyev, J. Argilaguet, J. Martinez, A. Meyerhans Human Immunodeficiency Virus Infection

[126] S. Jager, P. Cimermancic, N. Gulbahce, J.R. Johnson, K.E. McGovern, S.C. Clarke, M. Shales, G. Mercenne, L. Pache, K. Li, H. Hernandez, G.M. Jang, S.L. Roth, E. Akiva, J. Marlett, M. Stephens, I. D’Orso, J. Fernandes, M. Fahey, C. Mahon, A.J. O'Donoghue, A. Todorovic, J.H. Morris, D.A. Maltby, T. Alber, G. Cagney, F.D. Bushman, J.A. Young, S.K. Chanda, W.I. Sundquist, T. Kortemme, R.D. Hernandez, C.S. Craik, A. Burlingame, A. Sali, A.D. Frankel, N.J. Krogan. Global landscape of HIV-human protein complexes. Nature, 481(7381) (2012), 365-70.

[127] A.E. Jetzt, H. Yu, G.J. Klarmann, Y. Ron, B.D. Preston, J.P. Dougherty. High rate of recombination throughout the human immunodeficiency virus type 1 genome. Journal of virology, 74(3) (2000), 1234-40.

[128] M.I. Johnston, A.S. Fauci. An HIV vaccine-evolving concepts. The New England journal of medicine, 356(20) (2007), 2073-81.

[129] L. Josefsson, M.S. King, B. Makitalo, J. Brannstrom, W. Shao, F. Maldarelli, M.F. Kearney, W. S. Hu, J. Chen, H. Gaines, J.W. Mellors, J. Albert, J.M. Coffin, S.E. Palmer. Majority of CD4+ T cells from peripheral blood of $H I V$-1-infected individuals contain only one HIV DNA molecule. Proceedings of the National Academy of Sciences of the United States of America, 2011.

[130] A. Jung, R. Maier, J.P. Vartanian, G. Bocharov, V. Jung, U. Fischer, E. Meese, S. Wain-Hobson, A. Meyerhans. Recombination: Multiply infected spleen cells in HIV patients. Nature, 418(6894) (2002), 144.

[131] U.D. Kadolsky, B. Asquith. Quantifying the impact of human immunodeficiency virus-1 escape from cytotoxic Tlymphocytes. PLoS computational biology, 6(11) (2010), p. e1000981.

[132] A. Kamina, R.W. Makuch, H. Zhao. A stochastic modeling of early HIV-1 population dynamics. Mathematical biosciences, 170(2) (2001), 187-98.

[133] P.D. Katsikis, Y.M. Mueller, F.Villinger. The cytokine network of acute HIV infection: a promising target for vaccines and therapy to reduce viral set-point? PLoS pathogens, 7(8) (2011), p. e1002055.

[134] B.H. Keele, E.E. Giorgi, J.F. Salazar-Gonzalez, J.M. Decker, K.T. Pham, M.G. Salazar, C. Sun, T. Grayson, S. Wang, H. Li, X. Wei, C. Jiang, J.L. Kirchherr, F. Gao, J. A. Anderson, L.H. Ping, R. Swanstrom, G.D. Tomaras, W.A. Blattner, P.A. Goepfert, J.M. Kilby, M.S. Saag, E.L. Delwart, M.P. Busch, M.S. Cohen, D.C. Montefiori, B.F. Haynes, B. Gaschen, G.S. Athreya, H.Y. Lee, N. Wood, C. Seoighe, A.S. Perelson, T. Bhattacharya, B.T. Korber, B.H. Hahn, G.M. Shaw. Identification and characterization of transmitted and early founder virus envelopes in primary $H I V-1$ infection. Proceedings of the National Academy of Sciences of the United States of America, 105(21) (2008), 7552-7.

[135] P. Kiepiela, A.J. Leslie, I. Honeyborne, D. Ramduth, C. Thobakgale, S. Chetty, P. Rathnavalu, C. Moore, K.J. Pfafferott, L. Hilton. Dominant influence of $H L A-B$ in mediating the potential co-evolution of HIV and $H L A$. Nature, 432(7018) (2004), 769-75.

[136] F. Kirchhoff. Immune evasion and counteraction of restriction factors by $H I V-1$ and other primate lentiviruses. Cell host \& microbe, 8(1) (2010), 55-67.

[137] M.M. Kitahata, S.J. Gange, A.G. Abraham, B. Merriman, M.S. Saag, A.C. Justice, R.S. Hogg, S.G. Deeks, J.J. Eron, J.T. Brooks. Effect of early versus deferred antiretroviral therapy for HIV on survival. New England Journal of Medicine, 360(18) (2009), 1815-26.

[138] D. Klatzmann, F. Barre-Sinoussi, M.T. Nugeyre, C. Danquet, E. Vilmer, C. Griscelli, F. Brun-Veziret, C. Rouzioux, J.C. Gluckman, J.C. Chermann, and et al. Selective tropism of lymphadenopathy associated virus (LAV) for helperinducer T lymphocytes. Science, 225(4657) (1984), 59-63.

[139] R. Konig, Y. Zhou, D. Elleder, T.L. Diamond, G.M. Bonamy, J.T. Irelan, C.Y. Chiang, B.P. Tu, P.D. De Jesus, C.E. Lilley, S. Seidel, A.M. Opaluch, J.S. Caldwell, M.D. Weitzman, K.L. Kuhen, S. Bandyopadhyay, T. Ideker, A.P. Orth, L.J. Miraglia, F.D. Bushman, J.A. Young, S.K. Chanda. Global analysis of host-pathogen interactions that regulate early-stage HIV-1 replication. Cell, 135(1) (2008), 49-60.

[140] L.G. Kostrikis, G. Touloumi, R. Karanicolas, N. Pantazis, C. Anastassopoulou, A. Karafoulidou, J.J. Goedert, A. Hatzakis. Quantitation of human immunodeficiency virus type 1 DNA forms with the second template switch in peripheral blood cells predicts disease progression independently of plasma RNA load. Journal of virology, 76(20) (2002), 10099-108.

[141] I.N. Koulinska, E. Villamor, B. Chaplin, G. Msamanga, W. Fawzi, B. Renjifo, M. Essex. Transmission of cell-free and cell-associated HIV-1 through breast-feeding. AIDS, 41(1) (2006), 93.

[142] R.D. Kouyos, C.L. Althaus, S. Bonhoeffer. Stochastic or deterministic: what is the effective population size of HIV-1? Trends in microbiology, 14(12) (2006), 507-11.

[143] Y. Koyanagi, S. Miles, R.T. Mitsuyasu, J.E. Merrill, H.V. Vinters, I.S. Chen. Dual infection of the central nervous system by AIDS viruses with distinct cellular tropisms. Science, 236(4803) (1987), 819-22.

[144] H.B Kramer, K.J. Lavender, L. Qin, A.R. Stacey, M.K. Liu, K. di Gleria, A. Simmons, N. Gasper-Smith, B.F. Haynes, A.J. McMichael, P. Borrow, B.M. Kessler. Elevation of intact and proteolytic fragments of acute phase proteins constitutes the earliest systemic antiviral response in HIV-1 infection. PLoS pathogens, 6(5) (2010), p. e1000893.

[145] D. Kwa, J. Vingerhoed, B. Boeser-Nunnink, S. Broersen, H. Schuitemaker. Cytopathic effects of non-syncytiuminducing and syncytium-inducing human immunodeficiency virus type 1 variants on different $C D 4(+)-T$-cell subsets are determined only by coreceptor expression. Journal of virology, 75(21) (2001), 10455-9.

[146] P.D. Kwong, J.R. Mascola, G.J. Nabel. Rational Design of Vaccines to Elicit Broadly Neutralizing Antibodies to $H I V-1$. Cold Spring Harbor perspectives in medicine, 1(1) (2011), p. a007278.

[147] N. Laguette, B. Sobhian, N. Casartelli, M. Ringeard, C. Chable-Bessia, E. Segeral, A. Yatim, S. Emiliani, O. Schwartz, M. Benkirane. SAMHD1 is the dendritic- and myeloid-cell-specific HIV-1 restriction factor counteracted by Vpx. Nature, 474(7353) (2011), 654-7.

[148] D. Lecossier, F. Bouchonnet, F. Clavel, A.J. Hance. Hypermutation of HIV-1 DNA in the absence of the Vif protein. Science, 300(5622) (2003), 1112. 
G. Bocharov, V. Chereshnev, I. Gainova, S. Bazhan, B. Bachmetyev, J. Argilaguet, J. Martinez, A. Meyerhans Human Immunodeficiency Virus Infection

[149] S. Lederer, D. Favre, K.A. Walters, S. Proll, B. Kanwar, Z. Kasakow, C.R. Baskin, R. Palermo, J.M. McCune, M.G. Katze. Transcriptional profiling in pathogenic and non-pathogenic SIV infections reveals significant distinctions in kinetics and tissue compartmentalization. PLoS pathogens, 5(2) (2009), p. e1000296.

[150] H.Y. Lee, A.S. Perelson, S.C. Park, T. Leitner. Dynamic correlation between intrahost HIV-1 quasispecies evolution and disease progression. PLoS computational biology, 4(12) (2008), p. e1000240.

[151] M.C. Levesque, M.A. Moody, K.K. Hwang, D.J. Marshall, J.F. Whitesides, J.D. Amos, T.C. Gurley, S. Allgood, B.B. Haynes, N.A. Vandergrift, S. Plonk, D.C. Parker, M.S. Cohen, G.D. Tomaras, P.A. Goepfert, G.M. Shaw, J.E. Schmitz, J.J. Eron, N.J. Shaheen, C.B. Hicks, H.X. Liao, M. Markowitz, G. Kelsoe, D.M. Margolis, B.F. Haynes. Polyclonal B cell differentiation and loss of gastrointestinal tract germinal centers in the earliest stages of HIV-1 infection. PLoS Med., 6(7) (2009), p. e1000107.

[152] D.N. Levy, G.M. Aldrovandi, O. Kutsch, G.M. Shaw. Dynamics of HIV-1 recombination in its natural target cells. Proceedings of the National Academy of Sciences of the United States of America, 101(12) (2004), 4204-9.

[153] J.A. Levy, A.D. Hoffman, S.M. Kramer, J.A. Landis, J.M. Shimabukuro, L.S. Oshiro. Isolation of lymphocytopathic retroviruses from San Francisco patients with AIDS. Science, 225(4664) (1984), 840-2.

[154] S.G. Lim, A. Condez, C.A. Lee, M.A. Johnson, C. Elia, L.W. Poulter. Loss of mucosal CD4 lymphocytes is an early feature of HIV infection. Clinical and experimental immunology, 92(3) (1993), 448-54.

[155] P.F. Lindholm, K. Annen, G. Ramsey. Approaches to minimize infection risk in blood banking and transfusion practice. Infectious disorders drug targets, 11(1) (2011), 45-56.

[156] F. Lori, A. Malykh, A. Cara, D. Sun, J.N. Weinstein, J. Lisziewicz, R.C. Gallo. Hydroxyurea as an inhibitor of human immunodeficiency virus-type 1 replication. Science, 266(5186) (1994), 801-5.

[157] J.N. Mandl, A.P. Barry, T.H. Vanderford, N. Kozyr, R. Chavan, S. Klucking, F.J. Barrat, R.L. Coffman, S.I. Staprans, M.B. Feinberg. Divergent TLR7 and TLR9 signaling and type I interferon production distinguish pathogenic and nonpathogenic AIDS virus infections. Nature medicine, 14(10) (2008), 1077-87.

[158] L. Manganaro, M. Lusic, M.I. Gutierrez, A. Cereseto, G. Del Sal, M. Giacca. Concerted action of cellular JNK and Pin1 restricts HIV-1 genome integration to activated CD4+ T lymphocytes. Nature medicine, 16(3) (2010), 329-33.

[159] B. Mangeat, P. Turelli, G. Caron, M. Friedli, L. Perrin, D. Trono. Broad antiretroviral defence by human APOBEC3G through lethal editing of nascent reverse transcripts. Nature, 424(6944) (2003), 99-103.

[160] L.M. Mansky. Forward mutation rate of human immunodeficiency virus type 1 in a T lymphoid cell line. AIDS research and human retroviruses, 12(4) (1996), 307-14.

[161] L.M. Mansky. The mutation rate of human immunodeficiency virus type 1 is influenced by the vpr gene. Virology, 222(2) (1996), 391-400.

[162] L.M. Mansky, H.M. Temin. Lower in vivo mutation rate of human immunodeficiency virus type 1 than that predicted from the fidelity of purified reverse transcriptase. Journal of virology, 69(8) (1995), 5087-94.

[163] D.M. Margolis. Histone deacetylase inhibitors and HIV latency. Current opinion in HIV and AIDS, 6(1) (2011), 25-9.

[164] R. Mariani, D. Chen, B. Schrofelbauer, F. Navarro, R. Konig, B. Bollman, C. Munk, H. Nymark-McMahon, N.R. Landau. Species-specific exclusion of APOBEC3G from HIV-1 virions by Vif. Cell, 114(1) (2003), 21-31.

[165] N. Martin, Q. Sattentau. Cell-to-cell HIV-1 spread and its implications for immune evasion. Current opinion in HIV and AIDS, 4(2) (2009), 143-9.

[166] J.L. Marx. Circumcision may protect against the AIDS virus. Science, 245(4917) (1989), 470-1.

[167] J.R. Mascola, D.C. Montefiori. The role of antibodies in HIV vaccines. Annual review of immunology, 28(2010), 413-44.

[168] A.J. McMichael, P. Borrow, G.D. Tomaras, N. Goonetilleke, B.F. Haynes. The immune response during acute HIV-1 infection: clues for vaccine development. Nature reviews. Immunology, 10(1) (2010), 11-23.

[169] S. Mehandru, M.A. Poles, K. Tenner-Racz, A. Horowitz, A. Hurley, C. Hogan, D. Boden, P. Racz, M. Markowitz. Primary HIV-1 infection is associated with preferential depletion of CD4+ T lymphocytes from effector sites in the gastrointestinal tract. The Journal of experimental medicine, 200(6) (2004), 761-70.

[170] J.W. Mellors, A. Munoz, J.V. Giorgi, J.B. Margolick, C.J. Tassoni, P. Gupta, L.A. Kingsley, J.A. Todd, A.J. Saah, R. Detels, J.P. Phair, C.R. Rinaldo, Jr. Plasma viral load and CD4+ lymphocytes as prognostic markers of HIV-1 infection. Annals of internal medicine, 126(12) (1997), 946-54.

[171] J.W. Mellors, C. R. Rinaldo, Jr., P. Gupta, R.M. White, J. A. Todd, L. A. Kingsley. Prognosis in HIV-1 infection predicted by the quantity of virus in plasma. Science, 272(5265) (1996), 1167-70.

[172] A. Meyerhans, R. Cheynier, J. Albert, M. Seth, S. Kwok, J. Sninsky, L. Morfeldt-Manson, B. Asjo, S. Wain-Hobson. Temporal fluctuations in HIV quasispecies in vivo are not reflected by sequential HIV isolations. Cell, 58(5) (1989), 901-10.

[173] A. Meyerhans, J.P. Vartanian, C. Hultgren, U. Plikat, A. Karlsson, L. Wang, S. Eriksson, S. Wain-Hobson. Restriction and enhancement of human immunodeficiency virus type 1 replication by modulation of intracellular deoxynucleoside triphosphate pools. Journal of virology, 68(1) (1994), 535-40.

[174] S. Moir, A.S. Fauci. B cells in HIV infection and disease. Nature reviews. Immunology, 9(4) (2009), 235-45.

[175] V. Muller, A. F. Maree, R. J. De Boer. Small variations in multiple parameters account for wide variations in HIV-1 set-points: a novel modelling approach. Proceedings. Biological sciences / The Royal Society, 268(1464) (2001), 235-42.

[176] F. Nawaz, C. Cicala, D. Van Ryk, K.E. Block, K. Jelicic, J.P. McNally, O. Ogundare, M. Pascuccio, N. Patel, D. Wei, A.S. Fauci, J. Arthos. The genotype of early-transmitting HIV gp120s promotes alpha (4) beta(7)-reactivity, revealing alpha (4) beta (7) $+/ C D_{4}+T$ cells as key targets in mucosal transmission. PLoS pathogens, 7(2) (2011), p. e1001301. 
G. Bocharov, V. Chereshnev, I. Gainova, S. Bazhan, B. Bachmetyev, J. Argilaguet, J. Martinez, A. Meyerhans Human Immunodeficiency Virus Infection

[177] R. Nduati, G. John, D. Mbori-Ngacha, B. Richardson, J. Overbaugh, A. Mwatha, J. Ndinya-Achola, J. Bwayo, F.E. Onyango, J. Hughes, J. Kreiss. Effect of breastfeeding and formula feeding on transmission of HIV-1: a randomized clinical trial. JAMA: The Journal of the American Medical Association, 283(9) (2000), 1167-74.

[178] R.A. Neher, T. Leitner. Recombination rate and selection strength in HIV intra-patient evolution. PLoS computational biology, 6(1) (2010), p. e1000660.

[179] S.J. Neil, V. Sandrin, W.I. Sundquist, P.D. Bieniasz. An interferon-alpha-induced tethering mechanism inhibits HIV1 and Ebola virus particle release but is counteracted by the HIV-1 Vpu protein. Cell host \& microbe, 2(3) (2007), 193-203.

[180] S.J. Neil, T. Zang, P.D. Bieniasz. Tetherin inhibits retrovirus release and is antagonized by HIV-1 Vpu. Nature, 451(7177) (2008), 425-30.

[181] D.G. Nguyen, K.C. Wolff, H. Yin, J.S. Caldwell, K.L. Kuhen. "UnPAKing” human immunodeficiency virus (HIV) replication: using small interfering RNA screening to identify novel cofactors and elucidate the role of group I PAKs in HIV infection. Journal of virology, 80(1) (2006), 130-7.

[182] M.A. Nowak, R.M. May. Virus Dynamics. Mathematical Pronciples of Immunology and Virology Oxford University Press, Oxford, 2000.

[183] A. Okoye, M. Meier-Schellersheim, J.M. Brenchley, S.I. Hagen, J.M. Walker, M. Rohankhedkar, R. Lum, J.B. Edgar, S.L. Planer, A. Legasse, A.W. Sylwester, M. Piatak, Jr., J.D. Lifson, V.C. Maino, D.L. Sodora, D.C. Douek, M.K. Axthelm, Z. Grossman, L.J. Picker. Progressive CD4 + central memory T cell decline results in CD $4+$ effector memory insufficiency and overt disease in chronic SIV infection. The Journal of experimental medicine, 204(9) (2007), 2171-85.

[184] A. Onafuwa, W. An, N.D. Robson, A. Telesnitsky. Human immunodeficiency virus type 1 genetic recombination is more frequent than that of Moloney murine leukemia virus despite similar template switching rates. Journal of virology, $77(8)$ (2003), 4577-87.

[185] P. Paci, F. Martini, M. Bernaschi, G. D’Offizi, F. Castiglione. Timely HAART initiation may pave the way for a better viral control. BMC infectious diseases, 11(2011), 56.

[186] G. Pantaleo, A.S. Fauci. Immunopathogenesis of HIV infection. Annual review of microbiology, 50(1996), 825-54.

[187] G. Pantaleo, C. Graziosi, J.F. Demarest, L. Butini, M. Montroni, C.H. Fox, J.M. Orenstein, D.P. Kotler, A.S. Fauci. $H I V$ infection is active and progressive in lymphoid tissue during the clinically latent stage of disease. Nature, 362(6418) (1993), 355-8.

[188] A.S. Perelson, P. Essunger, Y. Cao, M. Vesanen, A. Hurley, K. Saksela, M. Markowitz, D.D. Ho. Decay characteristics of HIV-1-infected compartments during combination therapy. Nature, 387(6629) (1997), 188-91.

[189] A.S. Perelson, P. W. Nelson. Mathematical Analysis of HIV-1 Dynamics in Vivo. SIAM review. Society for Industrial and Applied Mathematics, 41(1999), 3-44.

[190] A.S. Perelson, A.U. Neumann, M. Markowitz, J.M. Leonard, D.D. Ho. HIV-1 dynamics in vivo: virion clearance rate, infected cell life-span, and viral generation time. Science, 271(5255) (1996), 1582-6.

[191] F. Pereyra, X. Jia, P.J. McLaren, A. Telenti, P.I. W. de Bakker, B.D. Walker, S. Ripke, C.J. Brumme, S.L. Pulit, M. Carrington. The major genetic determinants of HIV-1 control affect HLA class I peptide presentation. Science (New York, NY), 330(6010) (2010), 1551.

[192] D. Perrin, H.J. Ruskin, M. Crane. Model refinement through high-performance computing: an agent-based HIV example. Immunome research, 6 Suppl 1 (2010), p. S3.

[193] D.M. Phillips. The role of cell-to-cell transmission in HIV infection. AIDS, 8(6) (1994), 719-31.

[194] M. Piatak Jr., M.S. Saag, L.C. Yang, S.J. Clark, J.C. Kappes, K.C. Luk, B.H. Hahn, G.M. Shaw,J.D. Lifson. High levels of HIV-1 in plasma during all stages of infection determined by competitive PCR. Science, 259(5102) (1993), $1749-54$.

[195] L.J. Picker, S.I. Hagen, R. Lum, E.F. Reed-Inderbitzin, L.M. Daly, A.W. Sylwester, J.M. Walker, D.C. Siess, M. Piatak, Jr., C. Wang, D.B. Allison, V.C. Maino, J.D. Lifson, T. Kodama, M. K. Axthelm. Insufficient production and tissue delivery of CD $4+$ memory $T$ cells in rapidly progressive simian immunodeficiency virus infection. The Journal of experimental medicine, 200(10) (2004), 1299-314.

[196] M.M. Popovic, M.G. Sarngadharan, E. Read, R.C. Gallo. Detection, isolation, and continuous production of cytopathic retroviruses (HTLV-III) from patients with AIDS and pre-AIDS. Science, 224(4648) (1984), 497-500.

[197] K.A. Powers, A.C. Ghani, W.C. Miller, I.F. Hoffman, A.E. Pettifor, G. Kamanga, F.E. Martinson, M.S. Cohen. The role of acute and early HIV infection in the spread of HIV and implications for transmission prevention strategies in Lilongwe, Malawi: a modelling study. Lancet, 378(9787) (2011), 256-68.

[198] I. Puigdomenech, M. Massanella, C. Cabrera, B. Clotet, J. Blanco. On the steps of cell-to-cell HIV transmission between CD4 T cells. Retrovirology, 6(2009), 89.

[199] P. Racz, K. Tenner-Racz, C. Kahl, A.C. Feller, P. Kern, M. Dietrich. Spectrum of morphologic changes of lymph nodes from patients with AIDS or AIDS-related complexes. Progress in allergy, 37(1986), 81-181.

[200] S. Rato, S. Maia, P.M. Brito, L. Resende, C.F. Pereira, C. Moita, R.P. Freitas, J. Moniz-Pereira, N. Hacohen, L.F. Moita, J. Goncalves. Novel HIV-1 knockdown targets identified by an enriched kinases/phosphatases shRNA library using a long-term iterative screen in Jurkat T-cells. PLoS One, 5(2) (2010), p. e9276.

[201] S. Rerks-Ngarm, P. Pitisuttithum, S. Nitayaphan, J. Kaewkungwal, J. Chiu, R. Paris, N. Premsri, C. Namwat, M. de Souza, E. Adams, M. Benenson, S. Gurunathan, J. Tartaglia, J.G. McNeil, D.P. Francis, D. Stablein, D.L. Birx, S. Chunsuttiwat, C. Khamboonruang, P. Thongcharoen, M.L. Robb, N.L. Michael, P. Kunasol, J.H. Kim. Vaccination with ALVAC and AIDSVAX to prevent HIV-1 infection in Thailand. The New England journal of medicine, 361(23) (2009), 2209-20. 
G. Bocharov, V. Chereshnev, I. Gainova, S. Bazhan, B. Bachmetyev, J. Argilaguet, J. Martinez, A. Meyerhans Human Immunodeficiency Virus Infection

[202] T.D. Rhodes, O. Nikolaitchik, J. Chen, D. Powell, W.S. Hu. Genetic recombination of human immunodeficiency virus type 1 in one round of viral replication: effects of genetic distance, target cells, accessory genes, and lack of high negative interference in crossover events. Journal of virology, 79(3) (2005), 1666-77.

[203] J.D. Roberts, K. Bebenek, T.A. Kunkel. The accuracy of reverse transcriptase from HIV-1. Science, 242(4882) (1988), $1171-3$.

[204] L. Roberts, J. A. Passmore, C. Williamson, F. Little, L. M. Bebell, K. Mlisana, W. A. Burgers, F. van Loggerenberg, G. Walzl, J.F. Djoba Siawaya, Q. Abdool Karim, S.S. Karim. Plasma cytokine levels during acute HIV-1 infection predict HIV disease progression. AIDS, 24(6) (2010), 819-31.

[205] E.S. Rosenberg, M. Davidian, H.T. Banks. Using mathematical modeling and control to develop structured treatment interruption strategies for HIV infection. Drug and alcohol dependence, 88 Suppl 2 (2007), S41-51.

[206] M. Rotger, J. Dalmau, A. Rauch, P. McLaren, S.E. Bosinger, R. Martinez, N.G. Sandler, A. Roque, J. Liebner, M. Battegay, E. Bernasconi, P. Descombes, I. Erkizia, J. Fellay, B. Hirschel, J.M. Miro, E. Palou, M. Hoffmann, M. Massanella, J. Blanco, M. Woods, H.F. Gunthard, P. de Bakker, D.C. Douek, G. Silvestri, J. Martinez-Picado, A. Telenti. Comparative transcriptomics of extreme phenotypes of human HIV-1 infection and SIV infection in sooty mangabey and rhesus macaque. The Journal of clinical investigation, 121(6) (2011), 2391-400.

[207] I.M. Rouzine, J.M. Coffin. Linkage disequilibrium test implies a large effective population number for HIV in vivo. Proceedings of the National Academy of Sciences of the United States of America, 96(19) (1999), 10758-63.

[208] I.M. Rouzine, K. Murali-Krishna, R. Ahmed. Generals die in friendly fire, or modelling immune response to HIV. Journal of Computational and Applied Mathematic, 184(2005), 258-74.

[209] I.M. Rouzine, A. Rodrigo, J. M. Coffin. Transition between stochastic evolution and deterministic evolution in the presence of selection: general theory and application to virology. Microbiology and molecular biology reviews, 65(1) (2001), 151-85.

[210] D. Rudnicka, J. Feldmann, F. Porrot, S. Wietgrefe, S. Guadagnini, M. C. Prevost, J. Estaquier, A.T. Haase, N. Sol-Foulon, O. Schwartz. Simultaneous cell-to-cell transmission of human immunodeficiency virus to multiple targets through polysynapses. Journal of virology, 83(12) (2009), 6234-46.

[211] M.G. Sarngadharan, M. Popovic, L. Bruch, J. Schupbach, R.C. Gallo. Antibodies reactive with human T-lymphotropic retroviruses (HTLV-III) in the serum of patients with AIDS. Science, 224(4648) (1984), 506-8.

[212] Q. Sattentau. Avoiding the void: cell-to-cell spread of human viruses. Nature reviews. Microbiology, 6(11) (2008), 815-26.

[213] P.E. Sax, L. R. Baden. When to start antiretroviral therapy - ready when you are? New England Journal of Medicine, 360(18) (2009), 1897-9.

[214] T. Schaller, C. Goujon, M.H. Malim. AIDS/HIV. HIV interplay with SAMHD1. Science, 335(6074) (2012), $1313-4$.

[215] J.F. Scheid, H. Mouquet, N. Feldhahn, M.S. Seaman, K. Velinzon, J. Pietzsch, R.G. Ott, R.M. Anthony, H. Zebroski, A. Hurley, A. Phogat, B. Chakrabarti, Y. Li, M. Connors, F. Pereyra, B.D. Walker, H. Wardemann, D. Ho, R.T. Wyatt, J.R. Mascola, J.V. Ravetch, M.C. Nussenzweig. Broad diversity of neutralizing antibodies isolated from memory $B$ cells in HIV-infected individuals. Nature, 458(7238) (2009), 636-40.

[216] M. Schindler, J. Munch, O. Kutsch, H. Li, M.L. Santiago, F. Bibollet-Ruche, M.C. Muller-Trutwin, F.J. Novembre, M. Peeters, V. Courgnaud, E. Bailes, P. Roques, D.L. Sodora, G. Silvestri, P.M. Sharp, B.H. Hahn, F. Kirchhoff. Nef-mediated suppression of $T$ cell activation was lost in a lentiviral lineage that gave rise to HIV-1. Cell, 125(6) (2006), 1055-67.

[217] T. Schneider, H.U. Jahn, W. Schmidt, E.O. Riecken, M. Zeitz, R. Ullrich. Loss of CD4 T lymphocytes in patients infected with human immunodeficiency virus type 1 is more pronounced in the duodenal mucosa than in the peripheral blood. Berlin Diarrhea/Wasting Syndrome Study Group. Gut, 37(4) (1995), 524-9.

[218] H. Schuitemaker, N.A. Kootstra, R.E. de Goede, F. de Wolf, F. Miedema, M. Tersmette. Monocytotropic human immunodeficiency virus type 1 (HIV-1) variants detectable in all stages of HIV-1 infection lack T-cell line tropism and syncytium-inducing ability in primary T-cell culture. Journal of virology, 65(1) (1991), 356-63.

[219] A. Schultz, S. Sopper, U. Sauermann, A. Meyerhans, R. Suspene. Stable multi-infection of splenocytes during SIV infection - the basis for continuous recombination. Retrovirology, 9(1) (2012), 31.

[220] S. Schwartz, B.K. Felber, E.M. Fenyo, G.N. Pavlakis. Rapidly and slowly replicating human immunodeficiency virus type 1 isolates can be distinguished according to target-cell tropism in T-cell and monocyte cell lines. Proceedings of the National Academy of Sciences of the United States of America, 86(18) (1989), 7200-3.

[221] Y. Senturia, A. Ades, C. Peckham, C. Giaquinto, N. Baumslag. Breast-feeding and HIV infection. Lancet, 2(1987).

[222] L. Shan, K. Deng, N.S. Shroff, C.M. Durand, S.A. Rabi, H.C. Yang, H. Zhang, J.B. Margolick, J.N. Blankson, R.F. Siliciano. Stimulation of HIV-1-specific cytolytic T lymphocytes facilitates elimination of latent viral reservoir after virus reactivation. Immunity, 36(3) (2012), 491-501.

[223] R. Shankarappa, J.B. Margolick, S.J. Gange, A.G. Rodrigo, D. Upchurch, H. Farzadegan, P. Gupta, C.R. Rinaldo, G.H. Learn, X. He, X.L. Huang, J.I. Mullins. Consistent viral evolutionary changes associated with the progression of human immunodeficiency virus type 1 infection. Journal of virology, 73(12) (1999), 10489-502.

[224] A.M. Sheehy, N.C. Gaddis, J.D. Choi, M.H. Malim. Isolation of a human gene that inhibits HIV-1 infection and is suppressed by the viral Vif protein. Nature, 418(6898) (2002), 646-50.

[225] A.M. Sheehy, N.C. Gaddis, M.H. Malim. The antiretroviral enzyme APOBEC3G is degraded by the proteasome in response to HIV-1 Vif. Nature medicine, 9(11) (2003), 1404-7.

[226] H.W. Sheppard, M.S. Ascher, J.F. Krowka. Viral burden and HIV disease. Nature, 364(6435) (1993), $291-2$.

[227] N.M. Sherer, M. J. Lehmann, L. F. Jimenez-Soto, C. Horensavitz, M. Pypaert, W. Mothes. Retroviruses can establish filopodial bridges for efficient cell-to-cell transmission. Nature cell biology, 9(3) (2007), 310-5. 
G. Bocharov, V. Chereshnev, I. Gainova, S. Bazhan, B. Bachmetyev, J. Argilaguet, J. Martinez, A. Meyerhans Human Immunodeficiency Virus Infection

[228] T. Shioda, J. A. Levy, C. Cheng-Mayer. Macrophage and T cell-line tropisms of HIV-1 are determined by specific regions of the envelope gp120 gene. Nature, 349(6305) (1991), 167-9.

[229] K. Shirakawa, A. Takaori-Kondo, M. Yokoyama, T. Izumi, M. Matsui, K. Io, T. Sato, H. Sato, T. Uchiyama. Phosphorylation of APOBEC3G by protein kinase A regulates its interaction with HIV-1 Vif. Nature structural \& molecular biology, 15(11) (2008), 1184-91.

[230] D. Shriner, A.G. Rodrigo, D.C. Nickle, J.I. Mullins. Pervasive genomic recombination of HIV-1 in vivo. Genetics, 167(4) (2004), 1573-83.

[231] B. Siewe, A. Landay. Key Concepts in the Early Immunology of HIV-1 Infection. Current infectious disease reports, 14(1) (2012), 102-9.

[232] A. Sigal, J.T. Kim, A.B. Balazs, E. Dekel, A. Mayo, R. Milo, D. Baltimore. Cell-to-cell spread of HIV permits ongoing replication despite antiretroviral therapy. Nature, 477(7362) (2011), 95-8.

[233] J.D. Siliciano, J. Kajdas, D. Finzi, T.C. Quinn, K. Chadwick, J.B. Margolick, C. Kovacs, S.J. Gange, R.F. Siliciano. Long-term follow-up studies confirm the stability of the latent reservoir for HIV-1 in resting CD4+ T cells. Nature medicine, 9(6) (2003), 727-8.

[234] G. Silvestri, M.B. Feinberg. Turnover of lymphocytes and conceptual paradigms in HIV infection. The Journal of clinical investigation, 112(6) (2003), 821-4.

[235] P. Simmonds, P. Balfe, J.F. Peutherer, C.A. Ludlam, J.O. Bishop, A.J. Brown. Human immunodeficiency virusinfected individuals contain provirus in small numbers of peripheral mononuclear cells and at low copy numbers. Journal of virology, 64(2) (1990), 864-72.

[236] M. Sips, G. Sciaranghella, T. Diefenbach, A. S. Dugast, C.T. Berger, Q. Liu, D. Kwon, M. Ghebremichael, J.D. Estes, M. Carrington, J.N. Martin, S.G. Deeks, P.W. Hunt, G. Alter. Altered distribution of mucosal NK cells during HIV infection. Mucosal immunology, 5(1) (2012), 30-40.

[237] H. Soudeyns, G. Pantaleo. The moving target: mechanisms of HIV persistence during primary infection. Immunology today, 20(10) (1999), 446-50.

[238] A.E. Sousa, J. Carneiro, M. Meier-Schellersheim, Z. Grossman, R.M. Victorino. CD4 T cell depletion is linked directly to immune activation in the pathogenesis of HIV-1 and HIV-2 but only indirectly to the viral load. J. Immunol., 169(6) (2002), 3400-6.

[239] A.R. Stacey, P.J. Norris, L. Qin, E.A. Haygreen, E. Taylor, J. Heitman, M. Lebedeva, A. DeCamp, D. Li, D. Grove, S.G. Self, P. Borrow. Induction of a striking systemic cytokine cascade prior to peak viremia in acute human immunodeficiency virus type 1 infection, in contrast to more modest and delayed responses in acute hepatitis $B$ and C virus infections. Journal of virology, 83(8) (2009), 3719-33.

[240] M.A. Stafford, L. Corey, Y. Cao, E.S. Daar, D.D. Ho, A.S. Perelson. Modeling plasma virus concentration during primary HIV infection. Journal of theoretical biology, 203(3) (2000), 285-301.

[241] J.A. Sterne, M. May, D. Costagliola, F. de Wolf, A.N. Phillips, R. Harris, M.J. Funk, R.B. Geskus, J. Gill, F. Dabis, J.M. Miro, A.C. Justice, B. Ledergerber, G. Fatkenheuer, R.S. Hogg, A.D. Monforte, M. Saag, C. Smith, S. Staszewski, M. Egger, S.R. Cole. Timing of initiation of antiretroviral therapy in AIDS-free HIV-1-infected patients: a collaborative analysis of 18 HIV cohort studies. Lancet, 373(9672) (2009), 1352-63.

[242] C.A. Stoddart, R.A. Reyes. Models of HIV-1 disease: A review of current status. Drug Discovery Today: Disease Models, 3(2006), 113-119.

[243] M.C. Strain, H.F. Gunthard, D.V. Havlir, C.C. Ignacio, D.M. Smith, A.J. Leigh-Brown, T.R. Macaranas, R.Y. Lam, O.A. Daly, M. Fischer, M. Opravil, H. Levine, L. Bacheler, C.A. Spina, D.D. Richman, J.K. Wong. Heterogeneous clearance rates of long-lived lymphocytes infected with HIV: intrinsic stability predicts lifelong persistence. Proceedings of the National Academy of Sciences of the United States of America, 100(8) (2003), 4819-24.

[244] H. Streeck, J.S. Jolin, Y. Qi, B. Yassine-Diab, R.C. Johnson, D.S. Kwon, M.M. Addo, C. Brumme, J.P. Routy, S. Little, H.K. Jessen, A.D. Kelleher, F.M. Hecht, R.P. Sekaly, E.S. Rosenberg, B.D. Walker, M. Carrington, M. Altfeld. Human immunodeficiency virus type 1-specific CD8+ T-cell responses during primary infection are major determinants of the viral set point and loss of CD4 $+T$ cells. Journal of virology, 83(15) (2009), 7641-8.

[245] M.C. Stremlau, C.M. Owens, M.J. Perron, M. Kiessling, P. Autissier, J. Sodroski. The cytoplasmic body component TRIM5alpha restricts HIV-1 infection in Old World monkeys. Nature, 427(6977) (2004), 848-53.

[246] A.S. Sturt, M.S. Halpern, B. Sullivan, Y.A. Maldonado. Timing of Antiretroviral Therapy Initiation and its Impact on Disease Progression in Perinatal Human Immunodeficiency Virus-1 Infection. The Pediatric Infectious Disease Journal, 31(1) (2012), 53.

[247] C.F. Thobakgale, L. Fadda, K. Lane, I. Toth, F. Pereyra, S. Bazner, T. Ndung'u, B.D. Walker, E.S. Rosenberg, G. Alter, M. Carrington, T.M. Allen, M. Altfeld. Frequent and Strong Antibody-Mediated Natural Killer Cell Activation in Response to HIV-1 Env in Individuals with Chronic HIV-1 Infection. Journal of virology, 86(12) (2012), 6986-93.

[248] G.D. Tomaras, N.L. Yates, P. Liu, L. Qin, G.G. Fouda, L.L. Chavez, A.C. Decamp, R.J. Parks, V.C. Ashley, J.T. Lucas, M. Cohen, J. Eron, C.B. Hicks, H.X. Liao, S.G. Self, G. Landucci, D.N. Forthal, K.J. Weinhold, B.F. Keele, B.H. Hahn, M.L. Greenberg, L. Morris, S.S. Karim, W.A. Blattner, D.C. Montefiori, G.M. Shaw, A.S. Perelson, B.F. Haynes. Initial B-cell responses to transmitted human immunodeficiency virus type 1: virion-binding immunoglobulin $M(I g M)$ and $I g G$ antibodies followed by plasma anti-gp 41 antibodies with ineffective control of initial viremia. Journal of virology, 82(24) (2008), 12449-63.

[249] Y. Tsunetsugu-Yokota, K. Akagawa, H. Kimoto, K. Suzuki, M. Iwasaki, S. Yasuda, G. Hausser, C. Hultgren, A. Meyerhans, T. Takemori. Monocyte-derived cultured dendritic cells are susceptible to human immunodeficiency virus infection and transmit virus to resting $T$ cells in the process of nominal antigen presentation. Journal of virology, 69(7) (1995), 4544-7. 
G. Bocharov, V. Chereshnev, I. Gainova, S. Bazhan, B. Bachmetyev, J. Argilaguet, J. Martinez, A. Meyerhans Human Immunodeficiency Virus Infection

[250] N. Van Damme, D. Goff, C. Katsura, R.L. Jorgenson, R. Mitchell, M.C. Johnson, E.B. Stephens, J. Guatelli. The interferon-induced protein BST-2 restricts $H I V-1$ release and is downregulated from the cell surface by the viral Vpu protein. Cell host \& microbe, 3(4) (2008), 245-52.

[251] T. Van Montfort, A.A. Thomas, G. Pollakis, W.A. Paxton. Dendritic cells preferentially transfer CXCR4-using human immunodeficiency virus type 1 variants to CD4+ T lymphocytes in trans. Journal of virology, 82(16) (2008), 7886-96.

[252] A. Varela-Rohena, P. E. Molloy, S.M. Dunn, Y. Li, M.M. Suhoski, R.G. Carroll, A. Milicic, T. Mahon, D.H. Sutton, B. Laugel, R. Moysey, B.J. Cameron, A. Vuidepot, M.A. Purbhoo, D.K. Cole, R.E. Phillips, C.H. June, B.K. Jakobsen, A.K. Sewell, J.L. Riley. Control of HIV-1 immune escape by CD8 T cells expressing enhanced T-cell receptor. Nature medicine, 14(12) (2008), 1390-5.

[253] J.P. Vartanian, A. Meyerhans, B. Asjo, S. Wain-Hobson. Selection, recombination, and G- - - A hypermutation of human immunodeficiency virus type 1 genomes. Journal of virology, 65(4) (1991), 1779-88.

[254] D. Verotta. Models and estimation methods for clinical HIV-1 data. Journal of Computational and Applied Mathematics, 184(2005), 275-300.

[255] N.N. Vijay,R. Vasantika, R. Ajmani, A.S. Perelson, N.M. Dixit. Recombination increases human immunodeficiency virus fitness, but not necessarily diversity. The Journal of general virology, 89(2008), 1467-77.

[256] N. Wagner, J. Lohler, E.J. Kunkel, K. Ley, E. Leung, G. Krissansen, K. Rajewsky, W. Muller. Critical role for beta7 integrins in formation of the gut-associated lymphoid tissue. Nature, 382(6589) (1996), 366-70.

[257] S. Wain-Hobson. Viral burden in AIDS. Nature, 366(6450) (1993), 22.

[258] S. Wain-Hobson, P. Sonigo, O. Danos, S. Cole, M. Alizon. Nucleotide sequence of the AIDS virus, LAV. Cell, 40(1) (1985), 9-17.

[259] F. Wasserstein-Robbins. A mathematical model of HIV infection: Simulating T4, T8, macrophages, antibody, and virus via specific anti-HIV response in the presence of adaptation and tropism. Bulletin of mathematical biology, $72(5)$ (2010), 1208-53.

[260] X. Wei, S. K. Ghosh, M.E. Taylor, V.A. Johnson, E. A. Emini, P. Deutsch, J.D. Lifson, S. Bonhoeffer, M.A. Nowak, B.H. Hahn, and et al. Viral dynamics in human immunodeficiency virus type 1 infection. Nature, 373(6510) (1995), $117-22$.

[261] K. Wendelsdorf, G. Dean, S. Hu, S. Nordone, H.T. Banks. Host immune responses that promote initial HIV spread. Journal of theoretical biology, 289 (2011), 17-35.

[262] E.J. Wherry. T cell exhaustion. Nature immunology, 12(6) (2011), 492-9.

[263] WHO, posting date. Progress report 2011: Global HIV/AIDS response. [Online.]

[264] D. Wick, S. G. Self. Early HIV infection in vivo: branching-process model for studying timing of immune responses and drug therapy. Mathematical biosciences, 165(2) (2000), 115-34.

[265] R.D. Wiley, S. Gummuluru. Immature dendritic cell-derived exosomes can mediate HIV-1 trans infection. Proceedings of the National Academy of Sciences of the United States of America, 103(3) (2006), 738-43.

[266] F. Wong-Staal, G.M. Shaw, B.H. Hahn, S.Z. Salahuddin, M. Popovic, P. Markham, R. Redfield, R.C. Gallo. Genomic diversity of human T-lymphotropic virus type III (HTLV-III). Science, 229(4715) (1985), 759-62.

[267] T. Yamamoto, D.A. Price, J.P. Casazza, G. Ferrari, M. Nason, P.K. Chattopadhyay, M. Roederer, E. Gostick, P.D. Katsikis, D.C. Douek, R. Haubrich, C. Petrovas, R.A. Koup. Surface expression patterns of negative regulatory molecules identify determinants of virus-specific CD8+ T-cell exhaustion in HIV infection. Blood, 117(18) (2011), 4805-15.

[268] M.L. Yeung, L. Houzet, V.S. Yedavalli, K.T. Jeang. A genome-wide short hairpin RNA screening of jurkat T-cells for human proteins contributing to productive HIV-1 replication. The Journal of biological chemistry, 284(29) (2009), 19463-73.

[269] Y. Yuan, L.J. Allen. Stochastic models for virus and immune system dynamics. Mathematical biosciences, 234(2) (2011), 84-94.

[270] M. Zaitseva, A. Blauvelt, S. Lee, C.K. Lapham, V. Klaus-Kovtun, H. Mostowski, J. Manischewitz, H. Golding. Expression and function of CCR5 and CXCR4 on human Langerhans cells and macrophages: implications for HIV primary infection. Nature medicine, 3(12) (1997), 1369-75.

[271] M. Zeng, M. Paiardini, J.C. Engram, G.J. Beilman, J.G. Chipman, T.W. Schacker, G. Silvestri, A.T. Haase. Critical role of CD4 $T$ cells in maintaining lymphoid tissue structure for immune cell homeostasis and reconstitution. Blood, 120(9) (2012), 1856-67.

[272] H. Zhang, B. Yang, R. J. Pomerantz, C. Zhang, S.C. Arunachalam, L. Gao. The cytidine deaminase CEM15 induces hypermutation in newly synthesized HIV-1 DNA. Nature, 424(6944) (2003), 94-8.

[273] L. Zhang, P.J. Dailey, A. Gettie, J. Blanchard, D.D. Ho. The liver is a major organ for clearing simian immunodeficiency virus in rhesus monkeys. Journal of virology, 76(10) (2002), 5271-3.

[274] H. Zhou, M. Xu, Q. Huang, A.T. Gates, X.D. Zhang, J.C. Castle, E. Stec, M. Ferrer, B. Strulovici, D.J. Hazuda, A.S. Espeseth. Genome-scale RNAi screen for host factors required for HIV replication. Cell host \& microbe, 4(5) (2008), 495-504.

[275] J. Zhuang, A.E. Jetzt, G. Sun, H. Yu, G. Klarmann, Y. Ron, B.D. Preston, J.P. Dougherty. Human immunodeficiency virus type 1 recombination: rate, fidelity, and putative hot spots. Journal of virology, 76(22) (2002), $11273-82$. 